This manuscript has been published as:

D'Haen K, Verstraeten G and Degryse P. 2012 Fingerprinting historical fluvial sediment fluxes. Progress in

Physical Geography 36(2): 154-186.

\title{
Fingerprinting historical fluvial sediment fluxes
}

\author{
Koen D’Haen, KU Leuven, Belgium \\ Gert Verstraeten, KU Leuven, Belgium \\ Patrick Degryse, KU Leuven, Belgium
}

\author{
Corresponding author: \\ Department of Earth and Environmental Sciences, \\ KU Leuven, Celestijnenlaan 200E Box 2409, B-3001 Heverlee, Belgium \\ Email: koen.dhaen@ees.kuleuven.be
}

\begin{abstract}
In order to better understand the human impact on fluvial sediment dynamics at various timescales, information on the changing connectivity between the various geomorphic units in a landscape is crucial. Quantitative sediment budgets for various time periods provide a first assessment of changes in coupling between slopes and river systems. However, the application of sediment fingerprinting can yield additional spatial information on the sediment pathways. Furthermore, the fingerprint approach can also be used in cases where detailed sediment budgets are difficult to obtain. Provenance studies have been executed in various sedimentary environments, covering a wide variation of spatial and temporal scales. Here, an overview is provided of the tracer properties that can be used to distinguish between the various sediment sources in a river catchment. From this general compilation, those tracers useful to fingerprint fine grained floodplain deposits on a historical time scale (decadal to millennial) are distilled. Geochemical and mineralogical compositions, mineral magnetic signals and isotope ratios can be considered the most suitable fingerprinting properties. The impact of source area weathering, grain size selectivity of erosion and sedimentary processes and post-depositional alteration on tracer properties from source to sink are considered. Finally, a synopsis is made of the qualitative to fully quantitative approaches that can be used to discriminate the sources of fine grained alluvial sediments.
\end{abstract}

\section{Keywords}

Provenance, sediment fingerprinting, tracers, fluvial, historical 
This manuscript has been published as:

D'Haen K, Verstraeten G and Degryse P. 2012 Fingerprinting historical fluvial sediment fluxes. Progress in

Physical Geography 36(2): 154-186.

\section{Introduction}

Changing climate conditions and anthropogenic land-use changes are known to have impacted river systems (Macklin and Lewin, 2008). The way rivers respond to several forcing mechanisms, however, is very complex and still not completely understood. During the Holocene, climate conditions fluctuated considerably. Moreover, the Late Holocene is marked by ever increasing human impact (Goudie, 2006; Messerli et al., 2000). To gain insight in the interplay between climate and anthropogenic forcing on sediment dynamics, field observations are often used to obtain sedimentation rates for various time periods (e.g. Hoffmann et al., 2009) and to calculate sediment budgets (e.g. Verstraeten et al., 2009b). An important aspect of sediment dynamics is the geomorphic coupling and decoupling between various parts of a catchment (Fryirs and Brierley, 1999). Although sediment budgets provide useful information on sediment sources and sinks, and though this approach has been applied to catchments in many regions (e.g. Western Europe, Australia, USA), it cannot be used for all geomorphic settings. For instance, as shown by Dusar et al. (2011) it is not always straightforward to construct sediment budgets in Mediterranean catchments. Eastern Mediterranean river systems are more complex in nature. Their alluvial deposits have not been deposited continuously over the Holocene, but rather in several phases of cut and fill, which makes the application of alluvial architecture more difficult. Additionally, the cut and fill nature gives rise to numerous terraces within the alluvial plain. This makes it hard to determine the alluvial plain width, which in turn may increase the uncertainty on the calculated sediment budget. Moreover, due to a general lack of datable organic matter within the alluvial sediments, the establishment of a catchment-wide chronology of sediment deposition, and thus also the reconstruction of a time-differentiated sediment budget, is almost impossible. Therefore, it is only possible to construct a very general sediment budget for i.e. the entire Holocene deposition within river valleys in the Eastern Mediterranean. As a consequence, such sediment budgets, as opposed to e.g. Western Europe (Notebaert et al., 2009) are less informative on Holocene environmental changes. Sediment fingerprinting on the other hand allows to quantitatively determine the contributions of several spatially defined sediment sources. As demonstrated for contemporary (Evrard et al., 2011; Garzanti et al., 2006; Garzanti et al., 2007; Minella et al., 2008) and recent historical case studies (Walling et al., 2001; Walling et al., 1999), provenance information can be combined with sediment yield 
This manuscript has been published as:

D'Haen K, Verstraeten G and Degryse P. 2012 Fingerprinting historical fluvial sediment fluxes. Progress in Physical Geography 36(2): 154-186.

data and/or integrated into a sediment budget. To illustrate how sediment fingerprinting can contribute to unravelling historical sediment dynamics, a conceptual catchment is presented in Figure 1. While sediment budgets provide information regarding various types of erosion, deposition and sediment yield (Figure 1a), these fluxes refer more to processes than to spatially defined areas. However, when different lithologies present in this conceptual catchment are considered, the contributions of each of these areas to the floodplain deposits can be determined (Figure 1b). Given the distribution of lithological types within subcatchments, the contributions from these can be estimated (Figure 1c). Combining the information gained from both the sediment budget and the fingerprinting approach hence yields a better understanding of sediment dynamics.

The primary requirement of such an approach is that the possible sediment sources are sufficiently different. If the tracers used fail to properly discriminate potential sediment sources, it is not possible to apply a fingerprint approach. Moreover, the spatial distribution of the defined sources must show sufficient heterogeneity to allow a meaningful interpretation of sediment dynamics. It should be noted that in this paper only the provenance of floodplain deposits is considered. This method can, however, also be applied to colluvial deposits and exported sediment (e.g. fan or reservoir deposits), thereby further unravelling the sediment production and delivery processes operating at the catchment scale. Moreover, the fingerprinting method can also be applied in cases where sediment budgets cannot be constructed. There, it can provide useful information on the linkage between several geomorphic units on a historical time scale.

Although some research has been dedicated to fingerprint long-term river activity (Dearing et al., 2001; Hamlin et al., 2000), most sediment fingerprint studies focus on the provenance of suspended load of contemporary rivers (Collins et al., 1998; Davis and Fox, 2009; Gingele and De Deckker, 2005; Krishnappan et al., 2009; Minella et al., 2008) or (sub)recent alluvial sediments (Collins et al., 1997b; Foster et al., 2007; Owens and Walling, 2002; Owens et al., 1999; Walling et al., 2003). Research covering larger historical periods usually focuses on lacustrine (Foster et al., 2008; Revel-Rolland et al., 2005), deltaic (Ghilardi et al., 2008) or estuarine (Jenkins et al., 2002) environments or only yields qualitative provenance information (Amorosi et al., 2002; Foster and Lees, 1999). Much attention has also gone to provenancing Pleistocene gravel deposits (Jones, 2000) or even older sedimentary rocks. Overall, provenance studies have been conducted in a wide range of sedimentary environments, and on a wide range of temporal and spatial scales (Foster and Lees, 2000; 
This manuscript has been published as:

D'Haen K, Verstraeten G and Degryse P. 2012 Fingerprinting historical fluvial sediment fluxes. Progress in Physical Geography 36(2): 154-186.

Haughton et al., 1991; Honda et al., 2004; Walling, 2005; Weltje and von Eynatten, 2004; Yang et al., 2009; Yang et al., 2003). Although all these studies may have had entirely different objectives, they all tend to qualitatively or quantitatively determine sources of sedimentary materials using many different characteristics. Here, a general overview is given of tracer properties that may be used to determine the provenance of sediments, considering different time scales, spatial scales and sedimentary environments. The major aim thereof is to investigate human impact on sediment sources. The time window of interest is therefore the (Late) Holocene. Moreover, human impact is usually evaluated in the form of land use changes due to deforestation and the development of agriculture, making soil more vulnerable to erosion. This eroded material mainly consists of fine material, so the emphasis of this paper is on the provenance of the silt and clay fraction of floodplain deposits. As for spatial dimensions, the main interest is the study of entire river catchments, covering varying sizes, but beyond the scale of hill slope processes alone. Given these interests, tracer properties are evaluated on applicability, and different ways of processing tracer data are described, ranging from qualitative to fully quantitative approaches.

\section{Tracer properties}

The underlying assumption of all provenance studies is that potential sediment sources possess properties that allow them to be distinguished. These tracer properties need to be conservative, measurable and representative (Motha et al., 2002), so that the contributions from the different potential sources can be determined when comparing tracer properties of sources and sediments (Collins and Walling, 2002). The following overview is a synthesis of the tracer properties that have been applied in all kinds of provenance studies, covering both qualitative and quantitative approaches, on both recent and ancient systems, ranging from very local to regional studies, in aeolian, fluvial, coastal and marine settings. All tracers are evaluated according to their fields of applicability regarding time scale, spatial scale and grain size (Figure 2). It should be noted that the subdivision in different grain size, time and spatial classes is done in a rather qualitative way, because precise numbers are not readily available. The three grain size classes consist of clay and silt $(<63 \mu \mathrm{m})$, sand $(2 \mathrm{~mm}>\mathrm{x}>63 \mu \mathrm{m})$ and gravel $(>2 \mathrm{~mm})$. The subdivisions on a spatial scale range from local $\left(<10 \mathrm{~km}^{2}\right)$, over intermediate $\left(10-10000 \mathrm{~km}^{2}\right)$, to regional $\left(>10000 \mathrm{~km}^{2}\right)$ scales. With respect to the timescale, three time periods are considered in this review: contemporary (last 50 a), 
This manuscript has been published as:

D'Haen K, Verstraeten G and Degryse P. 2012 Fingerprinting historical fluvial sediment fluxes. Progress in

Physical Geography 36(2): 154-186.

historical (50 - 10000 a) and geological (>10 000 a). Here, the term "historical" refers to the period in the past when the environment was potentially susceptible to human activity, roughly coinciding with the (Late) Holocene.

\section{Physical properties}

A first important set of sediment properties that can be used to trace its origin are related to the physical characteristics of the sediment itself. These include the lithology of clasts, grain size distribution, grain morphology and the colour of the grains.

a Clast lithological analysis

In coarse deposits, a primary provenance indicator is often the lithological composition and shape related properties of the gravel. The lithology of gravels is not only assessed by visual inspection, but can also be evaluated by obtaining geochemical, isotopic or age information (Wandres et al., 2004a, 2004b). Besides qualitative approaches only accounting for the presence of certain lithologies, clast occurrences may also be counted to yield (semi)quantitative provenance determinations. Moreover, incorporating shape related properties can yield better provenance determinations (Lindsey et al., 2007). The advantage of this method is that it is very robust and can be applied on both ancient conglomerates (McDonnell and Craw, 2003; Wandres et al., 2004a, 2004b) and more recent gravel deposits (Bridgland, 1999; Lindsey et al., 2007; Miao et al., 2008).

\section{b Colour}

As one of the most basic properties, sediment colour has proven to be a useful source indicator in some case studies (Giosan et al., 2002; Krein et al., 2003). Early attempts (Grimshaw and Lewin, 1980) already documented the potential of sediment colour to document suspended sediment sources. In a recent study (Martinez-Carreras et al., 2010) the method was compared to more conventional tracer properties and has proven to be a fast and cheap alternative for traditional approaches.

c Grain size distributions

Although sorting effects create differences in the grain size distributions of sources and sediments, grain size distributions might still yield provenance information. Two approaches have been applied to calculate source contributions from grain size distributions. Kurashige and Fusejima (1997) compared hypothetical mixtures of two known sources with actual grain 
This manuscript has been published as:

D'Haen K, Verstraeten G and Degryse P. 2012 Fingerprinting historical fluvial sediment fluxes. Progress in Physical Geography 36(2): 154-186.

size distributions of suspended sediment samples. In marine environments, on the other hand, the exact number of sources might not be known and theoretical end-members can be constructed representing for example the contribution of aeolian and hemipelagic material (Stuut et al., 2002). Care should be taken, however, with the choice of an appropriate unmixing algorithm in order to decompose the grain size distribution of the sediment into realistic end-members (Weltje and Prins, 2007).

d Grain morphology

As rather qualitative data, characteristics such as the shape of aggregates (de Boer and Crosby, 1995; de Boer et al., 2000; Mazzullo and Withers, 1984) and the surface textures of certain minerals (Cardona et al., 2005; Madhavaraju et al., 2009) can yield additional provenance information.

\section{Mineralogical composition}

More important than the use of physical properties is the use of mineralogy to trace back sediment sources. Mineralogical tracers have been widely applied, and different mineral groups can be used. Whereas some studies take into account the bulk mineralogical composition of the sediments (Abu-Zeid et al., 2001; Arribas et al., 2000; Benedetti et al., 2006), others have focussed on clay minerals (Eberl, 2004a; Gingele and De Deckker, 2005) or the heavy mineral content (Basu and Molinaroli, 1991; Damiani and Giorgetti, 2008; Dill, 1998; Dinis and Soares, 2007; Ergin et al., 2007; Hounslow and Morton, 2004; Morton and Hallsworth, 1999; Oszczypko and Salata, 2005; Sabeen et al., 2002; Vezzoli et al., 2004; Vologina et al., 2007; von Eynatten and Gaupp, 1999). The choice of an appropriate method is obviously dependent on the grain size distribution of the sediment. Clay mineralogy is used for fine grained deposits and heavy mineral analysis is a classical provenance technique applied to sandy sediments. A more controversial and less straight forward technique is to use

the cathodoluminescence behaviour of quartz as a provenance indicator. Although this method might yield good results in some cases, it is not recommended to use it as a sole fingerprint (Bernet and Bassett, 2005; Boggs et al., 2002; Gotte and Richter, 2006; Gotze et al., 2001).

\section{Mineral magnetic signal}

The magnetic properties associated with soils and sediments are largely dominated by the presence of iron bearing minerals. The resulting magnetic signal is, however, not only 
This manuscript has been published as:

D'Haen K, Verstraeten G and Degryse P. 2012 Fingerprinting historical fluvial sediment fluxes. Progress in Physical Geography 36(2): 154-186.

affected by the mineralogy and geochemical composition of the phases in question, but also by size and shape-related properties (Dearing, 2000). Several magnetic parameters can be used, such as the magnetic susceptibility $\chi$ (low, high frequency and frequency dependent), magnetic remanence properties such as anhysteretic remanent magnetisation (ARM) and isothermal remanent magnetisation (IRM). Furthermore, derived remanence parameters ( $S$ ratio or HIRM) and magnetic ratios are often used. A comprehensive overview of magnetic properties is provided by Dearing et al.(2001) and by Foster et al. (2008). The signal derived from these parameters is often interpreted in terms of mineral assemblages. A distinction can be made between primary and secondary magnetic minerals. Where primary minerals are inherited directly from the parent material, secondary minerals are formed by pedogenic or biogenic processes. Moreover, it is believed that temperature may enhance the magnetic signal so burnt and unburnt soil can be distinguished (Blake et al., 2006; Oldfield and Crowther, 2007). As an alternative to classical magnetic measurements, the magnetic signal derived from mineral inclusions can be used (Hounslow and Morton, 2004; Maher et al., 2009).

Although there are clear links between mineralogy and magnetic parameters, there are still some problems regarding the interpretation of magnetic signals (Oldfield, 2007). Nevertheless magnetic tracers have been used in several sedimentary environments, ranging from aeolian (Hesse, 1997; Liu et al., 1999), coastal and marine settings (Ghilardi et al., 2008; Jenkins et al., 2002; Lees and Pethick, 1995; Liu et al., 2003; Wheeler et al., 1999) to lacustrine environments (Boar and Harper, 2002; Dearing et al., 2001; Foster et al., 2008; Hatfield and Maher, 2008; Hatfield et al., 2008; Shen et al., 2008; Walling et al., 2003) and fluvial systems (Caitcheon, 1998; Charlesworth and Lees, 2001; Chiverrell et al., 2008; Duck et al., 2001; Foster et al., 1998; Hatfield and Maher, 2009; Jenkins et al., 2002; Oldfield et al., 1999; Walden et al., 1997; Zhang et al., 2008).

\section{Geochemical composition}

Probably one of the most used fingerprint properties is the geochemical composition of sediments. This tracer property has been applied to an extensive range of settings, but in different ways. First of all the major and trace element composition, expressed on bivariant

"Harker" diagrams and normalised multi-element diagrams, so-called "spiderplots" (Rollinson, 1993), may yield qualitative information about a detrital input from potential source areas. For instance REE (Rare Earth Element) patterns provide information about 
This manuscript has been published as:

D'Haen K, Verstraeten G and Degryse P. 2012 Fingerprinting historical fluvial sediment fluxes. Progress in Physical Geography 36(2): 154-186.

possible contributions from several magmatic units, as REE patterns are excellent petrogenetic indicators (Wilson, 1989). This method is often applied on sedimentary rocks (Barovich and Hand, 2008; Il Lee, 2009; Kasanzu et al., 2008; Rahman and Suzuki, 2007), but may also be used to gain provenance information of dust (Jahn et al., 2001; Yang et al., 2007b) and recent stream sediments (Lee et al., 2008; Singh, 2009; Xu et al., 2009). Moreover, to reduce the effects of sorting and alteration, ratios of immobile elements may be used (Fralick and Kronberg, 1997). In quantitative sediment fingerprint studies geochemical tracers are quite popular because composite fingerprints comprising a set of different elements are often quite effective in discriminating potential sediment sources (Carter et al., 2003; Collins and Walling, 2002; Fu et al., 2006; Minella et al., 2008). Also, the geochemical compositions of specific minerals have proven to be valuable provenance indicators (Hallsworth and Chisholm, 2008; Morton, 1991; von Eynatten and Gaupp, 1999). This can be especially so when the potential sources form a continuum of geochemical compositions (e.g. volcanic successions) (Decou et al., 2009). The geochemical composition of both the light and heavy mineral fraction (Hardy et al., 2010) or of heavy minerals such as ilmenite (Bernstein et al., 2008; Grigsby, 1992), magnetite (Grigsby, 1990) and zircon (Grimes et al., 2007; Hoskin and Ireland, 2000) may allow to determine sediment provenance. Moreover the Si/Al ratio of white mica has proven to be a useful source indicator for sedimentary rocks (Wang et al., 2009).

\section{Biogeochemical tracers}

Biogeochemical tracers mainly consist of organic N, C and P. As these properties are dependent upon the organic matter content, they are suited for discriminating areas under different land use (Alt-Epping et al., 2009; Fox and Papanicolaou, 2008b; Hasholt, 1988; Hillier, 2001; McConnachie and Petticrew, 2006). In present day studies they can be used in combination with regular geochemical and radionuclide tracers. It should be noted that the enrichment or depletion of organic material can have a severe impact on the conservativeness of these tracers.

\section{Fall-out radionuclides}

The fall-out related radionuclides ${ }^{137} \mathrm{Cs}$ and ${ }^{210} \mathrm{~Pb}$ have often been used in shallow cores for dating purposes. These radionuclides have been moreover extensively used to study sediment redistribution (He et al., 1996; Van Oost et al., 2005). Beside these main applications, ${ }^{137} \mathrm{Cs}$ 
This manuscript has been published as:

D'Haen K, Verstraeten G and Degryse P. 2012 Fingerprinting historical fluvial sediment fluxes. Progress in Physical Geography 36(2): 154-186.

and ${ }^{210} \mathrm{~Pb}$ have proven to be valuable elements to obtain information about the contributions from areas under contrasting land use practices and on the proportion of surface to subsurface erosion (Davis and Fox, 2009). In the latter case they are usually combined with other (geochemical, mineral magnetic,...) tracer properties to yield better source discriminations (Carter et al., 2003; Collins and Walling, 2007; Foster et al., 2007; Gruszowski et al., 2003; Krause et al., 2003; Nagle and Ritchie, 2004; Russell et al., 2001; Wallbrink and Fogarty, 1998; Walling, 2005). In addition to these radionuclides, the naturally occurring cosmogenic radionuclide ${ }^{7} \mathrm{Be}$ can be used to study contemporary sediment dynamics (Evrard et al., 2010; Rhoton et al., 2008). There are, however, some important assumptions associated with the use of ${ }^{7} \mathrm{Be}$, for instance a spatially uniform input of ${ }^{7} \mathrm{Be}$ and a uniform distribution of any preexisting ${ }^{7} \mathrm{Be}$. Therefore, it is crucial to carefully plan field campaigns to meet the objectives put forward by the study (Mabit et al., 2008). The greatest disadvantage of these tracers is that their use is limited in time. Whereas ${ }^{7}$ be can only be applied on contemporary erosion events, the use of ${ }^{137} \mathrm{Cs}$ and ${ }^{210} \mathrm{~Pb}$ is limited to time scales of respectively 50 and 100 years. Finally, it should not be forgotten that the use of radionuclides implies some major assumptions. As indicated in a recent review on the use of ${ }^{137} \mathrm{Cs}$ by Parsons and Foster (2011) these assumptions might often not be valid and ${ }^{137} \mathrm{Cs}$ tends to show non-conservative behaviour.

\section{Cosmogenic radionuclides}

Earth materials contain cosmogenic radionuclides in different forms. These nuclides can be formed in the atmosphere and later on adsorbed on soil particles (meteoric), or be directly formed in certain minerals within the soil (in-situ). Cosmogenic nuclides have several applications, such as exposure and burial dating, calculating denudation and uplift rates and studying soil dynamics (Dunai, 2010). In addition to these applications, cosmogenic nuclides can be useful in provenance studies. Several studies (Belmont et al., 2007; Chappell et al., 2006; Clapp et al., 2002; Nichols et al., 2002; Perg et al., 2003) use in-situ ${ }^{10} \mathrm{Be}$ and ${ }^{26} \mathrm{Al}$ to distinguish sediment sources. The main application of these radionuclides is to calculate erosion rates and unravel sediment dynamics by using mass balance equations. Moreover, the target grain size classes consist of sand to gravel sized clasts, limiting the application to coarse deposits. Differences in radionuclide concentration between different grain size classes (sand versus gravel) can allow a quantification of hillslope and channel processes (Belmont et al., 2007). On the other hand, when quartz grains are not readily available, meteoric ${ }^{10} \mathrm{Be}$ and 
This manuscript has been published as:

D'Haen K, Verstraeten G and Degryse P. 2012 Fingerprinting historical fluvial sediment fluxes. Progress in Physical Geography 36(2): 154-186.

${ }^{26} \mathrm{Al}$ might be used instead (Willenbring and von Blanckenburg, 2010). Because of its very short half life (53.3 days) ${ }^{7} \mathrm{Be}$ is not used for in situ applications (Dunai, 2010). It can, however, be a useful tracer in contemporary studies as is discussed in the precious section.

\section{Isotope ratios}

In general a distinction can be made between stable $\left(\delta^{18} \mathrm{O}, \delta^{15} \mathrm{~N}, \delta^{13} \mathrm{C}, \delta^{66} \mathrm{Zn}, \delta^{67} \mathrm{Zn}, \delta^{68} \mathrm{Zn} \ldots\right)$ and radiogenic $\left(\varepsilon N d,{ }^{87} \mathrm{Sr} /{ }^{86} \mathrm{Sr},{ }^{208} \mathrm{~Pb} /{ }^{204} \mathrm{~Pb}, \quad{ }^{207} \mathrm{~Pb} /{ }^{204} \mathrm{~Pb}, \quad{ }^{206} \mathrm{~Pb} / 204 \mathrm{~Pb}, \varepsilon \mathrm{Hf},{ }^{187} \mathrm{Os} /{ }^{188} \mathrm{Os} \ldots\right)$ isotope ratios. While differences in stable isotope ratios are caused by fractionation processes, distinct radiogenic isotope ratios find their origin in differences in age or initial concentration of parent isotopes (Rollinson, 1993). Briefly this means that certain minerals, rocks or organic materials are characterised by distinct isotope ratio signatures, giving isotope ratios the potential to be good sediment source discriminators.

Similar to the corresponding elemental concentrations, the isotope ratios $\delta^{15} \mathrm{~N}$ and $\delta^{13} \mathrm{C}$ are used for tracing contributions from areas under contrasting land use in contemporary catchments (Alt-Epping et al., 2009; Fox and Papanicolaou, 2008a, 2008b). On the other hand the isotope ratios of $\mathrm{Nd}, \mathrm{Sr}$ and $\mathrm{Pb}$ are typically used in large scale provenance studies, such as those of aeolian sediment and dust (Borg and Banner, 1996; Grousset and Biscaye, 2005; Honda et al., 2004; Nakano et al., 2004; Yang et al., 2009), marine sediments (Bentahila et al., 2008; Carpentier et al., 2008; de Mahiques et al., 2008; Farmer et al., 2003; Tutken et al., 2002) or (meta-)sedimentary rocks (Barovich and Hand, 2008; Dantas et al., 2009). Isotope ratios have, however, also provided provenance information in moderate scale studies in lakes (Jin et al., 2006; Revel-Rolland et al., 2005; Zhou et al., 2009) and river catchments (Douglas et al., 1995; Gingele and De Deckker, 2005; Lee et al., 2008; Singh and France-Lanord, 2002; Yang et al., 2007a). In addition to these common used isotope ratios sometimes $\mathrm{Zn}$, Hf and Os isotope ratios are used (Bentahila et al., 2008; Grousset and Biscaye, 2005; Lupker et al., 2010). Although the use of this technique is rather limited, $\delta^{18} \mathrm{O}$ ratios can be applied to unravel the origin of quartz (Aleon et al., 2002; Neall et al., 2001; Yang et al., 2008) and chert (Dutta, 1998; Mizota et al., 1996). The great advantage of using isotope ratios as tracers is that they seem to be conservative on large scales, both spatially and temporally. The disadvantage is that values of isotope ratios often cover a wide range, so in most cases isotope ratios only yield qualitative to semi-quantitative provenance information, although there are exceptions (Gingele and De Deckker, 2005). 
This manuscript has been published as:

D'Haen K, Verstraeten G and Degryse P. 2012 Fingerprinting historical fluvial sediment fluxes. Progress in Physical Geography 36(2): 154-186.

\section{Mineral ages}

Within palaeographical reconstructions, mineral ages of zircon and monazite (Gleason et al., 2007; Kirkland et al., 2009; Nascimento et al., 2007; Schwartz and Gromet, 2004; Veevers and Saeed, 2007) and to a lesser extent muscovite (Reynolds et al., 2009) have been widely applied. If potential sediment sources contain a satisfactory amount of zircons with differing ages, zircon ages can also be powerful provenance indicators in present day studies (Amidon et al., 2005; Morton et al., 2008). To gain provenance information from mineral ages, the age distributions of selected minerals of the sediment are compared visually with the age distributions of the potential sources, yielding a qualitative provenance determination. If one wishes to gain quantitative provenance information, it could be an option to use an approach similar to the one used to un-mix grain size distributions (e.g. Weltje and Prins, 2007).

\section{Biogenic tracers}

Where biogenic inclusions in sediment are often indicators of sedimentary environment or (palaeo)climate, these characteristics may also be indicators of provenance when potential sediment sources contain a distinct set of biogenic species. These potential sources are usually themselves older sediments with for example a distinct of pollen or spores (Brown, 1985). In lacustrine and coastal settings the occurrence of ancient species of respectively diatoms (Vologina et al., 2007) or foraminifera (Haslett et al., 2000) can indicate the reworking of older sediments.

\section{Artificial tracers}

In present-day studies where natural properties fail to distinguish potential sediment sources, artificial properties can be added by man. The introduction of artificial tracers implies the major assumption that the material introduced acts the same way as the sediment itself. A large variety of artificial tracer techniques can be applied to trace very fine to coarse material. To document the erosion of fine sediments, labelled clays (Mahler et al., 1998a; Mahler et al., 1998b) or rare earth elements (REE) (Kimoto et al., 2006; Polyakov and Nearing, 2004) can be used. For tracing coarser sediments different sorts of tagged particles can be applied (Hassan and Ergenzinger, 2003; Sear et al., 2000). These techniques can be divided into visual (painted and fluorescent particles, exotic lithology), passive (radioactive, iron oxide coating, metal strips or plugs, iron cores, aluminium, natural and artificial magnetic, electronic) and active tracers (acoustic or radio tagged pebbles). Whereas visual tracers are 
This manuscript has been published as:

D'Haen K, Verstraeten G and Degryse P. 2012 Fingerprinting historical fluvial sediment fluxes. Progress in Physical Geography 36(2): 154-186.

quite cheap and easy to apply, passive tracers can be measured remotely. Active tracers on the other hand have the advantage that they yield continuous measurements, but their use is limited to large gravels and acoustic and radio transmitters are very expensive.

\section{General constraints}

Given this set of potential fingerprints, first of all some general constraints can be made concerning the application of certain tracer properties on different temporal and spatial scales, and for various sediment textures. As the temporal scale increases, there will be a larger potential for several processes to influence tracer concentrations and therefore some tracer properties are not conservative over longer time periods. Considering the spatial scale of the study, the spatial heterogeneity of tracer properties may restrict the use of certain tracers. Another restriction on the use of fingerprint properties is the grain size distribution of the sediments in question. Fine grained sediments will require other methods than a very coarse deposit. In general the sedimentary environment controls the dominant particle size of the sediments involved, with higher energy environments yielding coarser deposits. Considering the influence of grain size (sedimentary environment), time and spatial scale, different domains of application can be defined for different tracer properties (Figure 2). When the field of interest is the fingerprinting of historical alluvium sources, some additional constraints can be made concerning the application of fingerprints. For example, tracer properties that are only useful for present day studies (e.g artificial tracers) obviously should not be considered at all.

\section{Processes affecting tracer properties from source to sink}

As mentioned earlier, one of the main assumptions regarding tracer properties is that they are conservative. That is why it is important to know which potential controls there are on initial tracer concentrations and how these concentrations might be altered by sedimentary and postdepositional processes. Several processes might affect tracers from the moment the sediment is generated, during alluvial transport, when it is deposited and afterwards. Here the most important processes impacting the use of tracers for fingerprinting alluvial sediment at historical timescales are discussed, an overview is given in Figure 3. 
This manuscript has been published as:

D'Haen K, Verstraeten G and Degryse P. 2012 Fingerprinting historical fluvial sediment fluxes. Progress in Physical Geography 36(2): 154-186.

\section{Source area weathering and erosion}

The primary control on tracer properties is source area weathering. There are three main factors that determine the nature and degree of source area weathering, namely lithology, climate and topography. Where in many cases there is a clear link between soil parent material composition and lithology (Klassen, 2009) and the primary grain size distribution of sediment sources is dependent on the underlying lithology (Abraham et al., 1999), the nature of the topsoil depends mostly on the degree of weathering. Moreover chemical weathering has the ability to significantly alter sediment source compositions. Whereas the success of a provenance study largely depends on the degree that potential sources can be discriminated, the spatial distribution of potential sediment sources determines the spatial resolution that can be achieved. The spatial heterogeneity of the sources thus limits the spatial resolution of provenance determinations. In present day studies this heterogeneity can be enhanced with the use of artificial tracers (Collins et al., 2010b), whereas for studies on larger temporal scales, the distribution of different lithologies largely controls the attainable spatial resolution. As temperature and moisture determine the degree of chemical and physical weathering, the distribution of climatic zones defines spatial patterns of weathering (Pope et al., 1995). Longterm climatic fluctuations may also induce different weathering conditions resulting in temporal variations in sediment source compositions (Morton and Hallsworth, 1999). Next to climate, also the erosion rate relative to the weathering rate is important for understanding the composition of the regolith. If erosion goes faster than weathering, the characteristics of the parent material will be better preserved, whereas faster weathering will yield more altered material (Morton and Hallsworth, 1999). Topography is an important factor controlling both erosion and weathering rates. As weathering can have a profound impact on the composition of source materials, the degree of weathering can determine which tracers are available to differentiate between potential sediment sources. As weathered and un-weathered material can significantly differ in composition, both should be considered as potential sediment sources (Yu and Oldfield, 1993). This can be especially important for historical sediment fluxes as progressive erosion may induce an increasing contribution from un-weathered material.

\section{Size selectivity of erosion and sedimentary processes}


This manuscript has been published as:

D'Haen K, Verstraeten G and Degryse P. 2012 Fingerprinting historical fluvial sediment fluxes. Progress in Physical Geography 36(2): 154-186.

Although sediments will resemble to some degree the grain size distributions of their sources, generally speaking there will be a discrepancy between the grain size distributions of sediments and sources resulting from the size selectivity of erosion and sedimentary processes (Mclaren, 1981). As finer particles are more likely to be transported than larger ones, sediment carried by runoff has a higher proportion of fine grains than its source (Basic et al., 2002; Mclaren and Bowles, 1985; Stone and Walling, 1997). When considering suspended load on the other hand, the effect of selective erosion seems to be of minor importance when compared to preferential deposition during transport (Walling and Moorehead, 1989). During transport coarser grains tend to be preferentially deposited (Mclaren, 1981). It should be noted that presence of soil aggregates has a significant impact on the size selectivity of deposition processes (Beuselinck et al., 2000). The hydraulic behaviour of detritus is, however, not only a function of grain size, but also of density and grain shape. Whereas grain shape is an important factor for platy minerals, the hydraulic behaviour of most sub-spherical particles is controlled by size and density (Dietrich, 1982). Generally speaking the principle of hydraulic equivalence dictates smaller, denser grains to be deposited with larger, lighter grains. On the other hand particles that are settling-equivalent are not necessarily equally prone to entrainment. During the reworking of sediment, coarser but less dense particles tend to be easier entrained than smaller but denser particles (Garzanti et al., 2008). In this way, heavy minerals can be accumulated, but also ratios of more and less dense (heavy) minerals can be altered, resulting in compositional heterogeneities within deposits (Garcia et al., 2004).

Besides sorting effects, several wearing mechanisms are responsible for the abrasion of sedimentary particles. Where sorting will result in the concentration of different mineral groups into different grain size classes, abrasion will cause weaker clasts to break down into finer particles, resulting in a gradual concentration of more resistant particles in coarser grain size classes and vice versa. Although the effects of abrasion are certainly important on coarse particles in high-energy sedimentary environments (Kodama, 1994a, 1994b; Whitmore et al., 2004), there seems to be no significant effects of abrasion on large sand-bed rivers (Frings, 2008).

Typically, sand and clay to silt sized deposits with a similar provenance can have distinct compositions due to the accumulation of different types of minerals in different grain size classes (Ohta, 2004, 2008). Sorting effects moreover cause shifts in composition between bed 
This manuscript has been published as:

D'Haen K, Verstraeten G and Degryse P. 2012 Fingerprinting historical fluvial sediment fluxes. Progress in Physical Geography 36(2): 154-186.

load, suspended load and floodplain deposits (Singh, 2009). The compositional discrepancy between different particle size classes originates during source area weathering, as less stable grains are more readily decomposed to finer particles (Nesbitt et al., 1996). Moreover, metals seem to be concentrated in the fine fraction of sediment (Stamoulis et al., 1996). As chemical weathering is expected to impose linear trends on composition versus grain size, physical processes tend to create stepwise patterns of composition in function of grain size (TolosanaDelgado and von Eynatten, 2010). Although there are some strong relations between grain size and sediment composition, surface area is likely to be equally important (Horowitz and Elrick, 1987).

Finally, not only the input of detrital material is determining the composition of sediments, also the biogenic flux of organic and skeletal material can have an important influence on sediment composition (Sageman and Lyons, 2003). In particular differences in organic matter content between sources and sediment can yield erroneous provenance determinations as organic matter has an important influence on the geochemical and radionuclide composition (Hirner et al., 1990).

As discussed above, different stages of weathering and hydraulic sorting yield compositional differences between different grain size classes. This not only implies that different grain size classes from a deposit with a similar provenance can differ in composition, but also that the different grain size classes within a deposit can have a distinct provenance (Benedetti et al., 2006; Eberl, 2004b; Piper et al., 2006; Thoms et al., 2008). It is therefore important to split both the sediments and their potential sources in a range of representative grain size classes and focus on one class or study the different classes separately. Moreover, different particle size classes can require different tracers to unravel their provenance. The question is where to draw the line. First of all, a distinction can be made between suspended load and bed load. Whereas for bed load, gravel- and sand-sized should be treated separately, further subdividing the sand fraction may yield erroneous provenance determinations (Garzanti et al., 2009). For suspended load a strong grain size control on sediment composition has been recognised, but nevertheless the $<63 \mu \mathrm{m}$ fraction seems to be representative (Horowitz and Elrick, 1987).

\section{Post-depositional alteration of alluvial sediment properties}

After deposition, sediments are prone to a range of processes related to soil formation and weathering. First of all, leaching of unstable minerals (Morton and Hallsworth, 1999) can result in altered mineralogical and geochemical compositions. As for source area weathering, 
This manuscript has been published as:

D'Haen K, Verstraeten G and Degryse P. 2012 Fingerprinting historical fluvial sediment fluxes. Progress in Physical Geography 36(2): 154-186.

the degree of leaching is strongly climate dependent. Besides climate, the sedimentary environment needs to be considered as well. For instance, in coastal areas rising sea levels can introduce salt water into sediments causing cation exchange reactions resulting in an alteration of certain elements, as has been demonstrated for ${ }^{137} \mathrm{Cs}$ in coastal lagoons in SW England (e.g. Foster et al., 2006). Moreover oxido-reduction reactions associated with groundwater table variations may result in the solution of Fe-bearing minerals, which are the key feature for magnetic measurements (Dearing, 2000). Besides the destruction of minerals, also new phases can be formed, e.g. authigenic carbonate and bacterial Fe-oxides. Finally, sediments may be disturbed by biological activity, mixing sediments of different ages or adding organic material to the deposits.

Consequently, care should be taken when appropriate tracers are selected for provenancing floodplain deposits and potentially unstable phases should be avoided. To get an idea of the degree of weathering within the floodplain, detailed field observations are necessary and furthermore several geochemical indexes of weathering can be used (Burke et al., 2007; Le Pera et al., 2001; Roy et al., 2008).

\section{Suitable fingerprints for historical alluvial sediments}

A state of the art overview is provided in Figure 4, in which the number of alluvial provenance studies is represented for each temporal, spatial and grain size class.

As tracers have different fields of application regarding grain size, the type of floodplain will imply some constraints regarding the use of fingerprints. The provenance determination of a coarse gravel deposits will obviously require a different approach than the study of a fine grained deposit. Moreover due to weathering and hydraulic sorting different size fraction may be characterized by a distinct composition and/or provenance. Therefore, it is necessary to split sediments in different grain size fractions and study those fractions separately or focus on one specific size fraction. The chosen fraction(s) should of course be representative for the deposit being studied. As in this paper the main concern is to study the anthropogenic impact on soil erosion on a historical time scale, the grain size window is the clay and silt fraction. The field of interest is thus to unravel the provenance of fine grained $(<63 \mu \mathrm{m})$ alluvial sediment on a historical time scale $(50-10000$ a) and an intermediate catchment scale (10 $\left.10000 \mathrm{~km}^{2}\right)$. 
This manuscript has been published as:

D'Haen K, Verstraeten G and Degryse P. 2012 Fingerprinting historical fluvial sediment fluxes. Progress in Physical Geography 36(2): 154-186.

As shown in Figure 4, most research is conducted on contemporary river systems. Popular fingerprints in present-day studies for fine grained fluvial sediments are geochemical tracers, fall-out radionuclides and mineral magnetic signals (Figure 5). However, when the spatial scale increases, geochemical tracers maintain their dominant position, but other properties diminish, making place for mineralogical tracers and isotope ratios. Shifting to larger temporal scales will put some constraints on the use of certain tracers, for instance biogeochemical tracers are not conservative beyond the scale of contemporary studies and the use of radionuclides is limited to recent historical (50 - 100 a) research (e.g. Mabit et al., 2008). The number of tracer groups that have been applied for fingerprinting fine sediment on a historical time scale is rather limited, only geochemical tracers, radionuclides, mineral magnetic tracers and physical properties have been used (Figure 5). This is mainly because of the low number of studies in this field and does not mean that other properties cannot be useful. Furthermore, a large proportion of these studies were performed on deposits from the last 200 years, and hence the main reason for the position of radionuclides. As shown by the more general overview provided in Figure 2, both mineralogical tracers and isotope ratios show great potential to fingerprint historical alluvium (Figure 2). Especially the isotope ratios of $\mathrm{Nd}, \mathrm{Sr}$ and $\mathrm{Pb}$ might be useful, because of their conservative nature.

Processes that affect tracers after deposition should be considered as well. Not all tracers used in contemporary studies are necessarily conservative on a historical time scale due to postdepositional alteration processes. The use of tracer properties that are potentially not conservative should hence be avoided. For instance, the formation of secondary ferrimagnetic minerals and the reductive transformation of iron-bearing minerals can have a severe impact on the magnetic signal derived from floodplain deposits. Although mineral magnetic tracers have been used in historical studies (e.g. Foster et al., 2007; Ghilardi et al., 2008; Owens et al., 1999), sometimes it might be favourable to use magnetic inclusions instead (Hounslow and Morton, 2004; Maher et al., 2009). When certain minerals are leached after deposition, specific extraction methods can be used to focus on the composition of the geochemically stable phases. For instance, if the carbonate fraction behaves non-conservatively due to solution phenomena or the formation of authigenic carbonate nodules, the carbonate-free geochemical signal can be used instead of the bulk composition. Moreover, in low-energy sedimentary environments, floodplain deposits can contain a considerable amount of organic 
This manuscript has been published as:

D'Haen K, Verstraeten G and Degryse P. 2012 Fingerprinting historical fluvial sediment fluxes. Progress in Physical Geography 36(2): 154-186.

material. As this can have a significant impact on the geochemical composition of the sediment, the organic material should be removed prior to analysis.

To illustrate use of tracers on historical alluvium, three case studies are considered. As mentioned before, popular fingerprints used on a historical time scale consist of geochemical and mineral magnetic properties (Figure 5). Collins et al. (1997b), for instance, used geochemical fingerprints to identify the sediment sources of recent historical flooplain deposits (100 a) of the Exe and Severn catchments, UK. While in the Exe catchment sediment sources remained constant over time, except for a flood in 1960, sediment sources changed considerably through time in the Severn catchment (Figure 6). This is a nice illustration of how two different catchments, both prone to land use changes, show a distinct response to human impact.

Foster et al. (1990) on the other hand used mineral magnetic fingerprints to determine historical (1765 - 1853) and contemporary (1986 - 1987) sediment yields and sources of the Seeswood and Merevale catchments in Midland England. The sediment source area model of the Seeswood catchment (Figure 7) shows the change of sediment sources through time and its significant impact on sediment yield. Especially the contributions from sliding banks and poaching in the northern stream have significantly increased through time. This example is a nice illustration of the advantage of incorporating provenance data into sediment budgets. Finally, Hamlin et al. (2000) studied sediment dynamics on a much larger temporal scale (Pleistocene to recent) to elucidate the response of the Voidomatis river in North-west Greece to climatic cycles (Figure 8a). Both geochemical and mineral magnetic properties were used to differentiate sources and calculate their contributions. The first cold sedimentation phase following the last interglacial is characterised by a notable input of flysch material, which had been prone to weathering and soil development during the preceding warmer period. Later cold fine sediment fluxes are dominated by material derived from the limestone areas, reflecting the importance of glacial weathering and erosion. The post-glacial period was characterised by advancing incision due to the decline of glacial erosion and the stabilisation of slopes by vegetation. Only in the Late Holocene higher rates of sediment accumulation were recorded, with elevated inputs from the flysch area (Figure 8b). In all three examples mentioned, a quantitative approach was used, namely a linear mixing model. More information about possible approaches is given in the following section. 
This manuscript has been published as:

D'Haen K, Verstraeten G and Degryse P. 2012 Fingerprinting historical fluvial sediment fluxes. Progress in

Physical Geography 36(2): 154-186.

\section{Sediment source ascription}

Given a set of suitable tracers, the data obtained can be processed in different ways to yield a provenance determination of the deposits in question (Foster and Lees, 2000; Walden et al., 1997). These approaches range from qualitative means of describing likely sources of sediment to quantitative mixing models that actually allow to calculate the contributions from different potential sediment sources. Although the ultimate goal is a quantitative assessment of sediment provenance, it is very useful to start with a qualitative inspection of the tracer data. An overview of different approaches is provided in Figure 9.

It should also be mentioned that some tracer properties consist of compositional data, being proportions or percentages, often referred to as closed data because they sum up to some constant, equal to 1 for proportions, 100 for percentages or another constant depending on the unit of the data. Care should be taken when analysing such data and appropriate transformations might be needed before applying certain multivariate techniques (Aitchison, 1986).

\section{Biplots and Ternary diagrams}

The simplest method is to use biplots of sediment tracing properties to explore which of the potential sources has the greatest affinity with the sediments in question. Moreover this approach provides a first indication of which tracers best discriminate the potential sediments sources. Although only yielding qualitative results, plots of geochemical element ratios provide robust provenance information, not biased by sorting effects or post-depositional alteration and thus conservative on large temporal scales (Fralick and Kronberg, 1997). Besides biplots, ternary plots are also quite popular for provenance determinations. However, when tracers are plotted in a ternary diagram, a closure operation is performed, making the data compositional. Because different tracers can differ significantly in order of magnitude, compositions may plot close the boundaries of the ternary diagram. To circumvent this problem and gain a better visualisation the data can be centred on the plot (von Eynatten et al., 2002). Moreover compositional trends can be described mathematically, yielding quantitative information about processes influencing sediment composition (von Eynatten, 2004). Garzanti et al. (2006) used a ternary diagram to describe the mineralogical 
This manuscript has been published as:

D'Haen K, Verstraeten G and Degryse P. 2012 Fingerprinting historical fluvial sediment fluxes. Progress in Physical Geography 36(2): 154-186.

composition of Nile river sands (Figure 10). Although this plot clearly indicates that different river sections are characterised by different sediment sources, reworking and weathering, quantitative information about the linkage between different parts of the catchment cannot be directly derived from this plot.

\section{Statistical approaches}

One of the basic requirements of tracer properties is that they clearly differ between different potential sediment sources. Moreover, it is often useful to identify the smallest set of tracers that allows to distinguish sediment sources, a so called optimum fingerprint (Collins et al., 1997a). To investigate the suitability of tracers, several statistical approaches can be used. At first the tracers significantly different between the sources need to be identified. When selected tracer properties are normally distributed, the Tukey test can be utilised. However, if tracer properties are not characterised by normal distributions, as is often the case, nonparametric tests are more powerful. When there are only two potential sediment sources, the Mann-Whitney U-test, also known as the Wilcoxon rank sum test, can be applied. In the more common case, where there are more than two potential sources, the Kruskal-Wallis H-test can be used (Davis and Fox, 2009). Once significantly tracers have been identified, multivariate techniques can be used to test which properties best distinguish the different sources. However, one should always consider the underlying assumption made when applying multivariate techniques. One of these assumptions is that the data analysed are normally distributed. As already mentioned, this is often not the case. An additional issue is that data can be compositional. To cope with these difficulties, it can be useful to apply transformations to the data (e.g. Reimann et al., 2008). One of the most applied methods to determine the "optimum fingerprint" is linear discriminant analysis. This multivariate method is used to estimate a relationship between a non-metric dependent variable (sources) and a set of metric independent variables (tracers) (Hair et al., 1998). To identify the "optimum fingerpint" a stepwise procedure is used based on the minimisation of Wilks' Lambda (Collins et al., 1997a). This is a test statistic used in multivariate analysis of variance to check for differences between the means of predefined groups on a combination of dependent variables (Everitt and Dunn, 2001). Similar to discriminant analysis, it is also possible to apply logistic regression on compositional data. . Thomas and Aitchison (2005) used binary logistic 
This manuscript has been published as:

D'Haen K, Verstraeten G and Degryse P. 2012 Fingerprinting historical fluvial sediment fluxes. Progress in

Physical Geography 36(2): 154-186.

regression to select the geochemical sub-composition that best differentiates two types of limestone.

In addition to statistical approaches that allow to identify the best discriminating tracers, it might be useful to apply data reduction methods such as principal component analysis (PCA) or Factor analysis to visualise data (Hardy et al., 2010; Piper et al., 2006). Especially in the case where a large number of tracers is used this may be handy. Moreover, related variables can be grouped according to the loadings on different components (Ohta, 2004). When applying multivariate techniques on compositional (closed) data, one should always bear in mind to apply appropriate data transformations (Filzmoser et al., 2009; Reimann et al., 2008).

\section{Linear mixing models}

Finally, to yield a quantitative source ascription, multivariate linear mixing models are developed. It should be noted that only properties that are linear additive can be used in these linear models. It has been shown that certain magnetic properties are not linear additive (Lees, 1997) and although elemental ratios tend to be robust measures (Fralick and Kronberg, 1997), they seem to be not linear additive and cannot be used in linear mixing models (Walling, 2005). In this linear modelling approach the sediment sources are regarded as end-member compositions of which the contributions to different sediment samples can be calculated (Renner, 1993). If the sediments would be perfect mixtures of the sources, a series of linear equations could be written that expresses sediment samples as unknown proportions of sediment sources.

$$
\begin{aligned}
\multicolumn{1}{l}{\mathrm{M}_{\mathrm{i}}=\mathrm{P}_{1} \mathrm{~S}_{1 \mathrm{i}}+\ldots+\mathrm{P}_{\mathrm{n}} \mathrm{S}_{\mathrm{ni}}} \\
\ldots \\
\mathrm{M}_{\mathrm{m}}=\mathrm{P}_{1} \mathrm{~S}_{1 \mathrm{~m}}+\ldots+\mathrm{P}_{\mathrm{n}} \mathrm{S}_{\mathrm{nm}} \\
\mathrm{M}=\mathrm{PS} \quad \mathrm{P}_{1}+\ldots+\mathrm{P}_{\mathrm{n}}=1 \quad \mathrm{P}_{1}, \ldots, \mathrm{P}_{\mathrm{n}} \geq 0
\end{aligned}
$$


This manuscript has been published as:

D'Haen K, Verstraeten G and Degryse P. 2012 Fingerprinting historical fluvial sediment fluxes. Progress in Physical Geography 36(2): 154-186.

Where $\mathrm{M}_{\mathrm{i}}$ represents the concentration of tracer $\mathrm{i}$ in a sediment sample, $\mathrm{S}_{\mathrm{ji}}$ the concentration of tracer $\mathrm{i}$ in source $\mathrm{j}$ and $\mathrm{P}_{\mathrm{j}}$ the proportion of source $\mathrm{j}$, given that there are $\mathrm{m}$ tracers and $\mathrm{n}$ sources. In reality the sediments will not be perfect mixtures of the source end-members, so the system should better be described with

$M=P S+E$

Where E represents the tracer concentration discrepancy between the natural sediment and the simulated mixtures. Furthermore, in many cases there are more tracers than sources, so the number of equations exceeds the number of unknowns and the system is over-determined.

There are several ways to solve such a system. One way is to minimise the sum of squares of the errors between the calculated and actual sediment composition (Collins et al., 1996). To reduce the complexity of over-determined systems, a set of linear combinations of the variables can be used instead of the tracer data itself. For this purpose, data reduction methods such as PCA can be applied (Liu et al., 2008). Another way to solve the system is to describe the tracers of each source with multivariate normal distributions. With the help of Bayesian statistics, a probabilistic solution for the system can be found. The posterior distribution of all unknown parameters, including the proportions of the sources, is determined via Markov Chain Monte Carlo simulation (Fox and Papanicolaou, 2008b). This approach is moreover applicable to compositional data as they have a logistic normal distribution (Aitchison and Bacon-Shone, 1999; Billheimer, 2001). An advantage of the Bayesian approach is that spatial variability can be implemented in the model (Palmer and Douglas, 2008).

The fact that in the Bayesian approach sediment source compositions are represented by distributions points out that sources are not fixed compositions, but are defined by a cluster of observations (Aitchison and Bacon-Shone, 1999). The resulting posterior distribution thus gives an idea of the uncertainty associated with the source ascription. Small et al. (2002) showed that this uncertainty is largely dependent on the number of samples in each source group, with more source group samples (twenty to hundred) significantly reducing uncertainty. To incorporate the variation of the source composition in the least squares method and get an idea of the uncertainty, a Monte Carlo approach is used and tracers are randomly sampled from their distributions (Collins et al., 2010a; Joerin et al., 2002; MartinezCarreras et al., 2008; Rowan et al., 2000). This will yield probability density functions of the 
This manuscript has been published as:

D'Haen K, Verstraeten G and Degryse P. 2012 Fingerprinting historical fluvial sediment fluxes. Progress in

Physical Geography 36(2): 154-186.

contributions from the different sources. To reduce the uncertainty of the model and cope with different factors that influence sediment composition, it is possible to implement a series of correction factors to take account differences in grain size distribution and organic material content between sources and sediments, the within-source variation of each tracer property and to weigh the different tracer properties according to their ability to distinguish potential sources (Collins et al., 2010a). Although the effects of sorting on sediment composition are widely recognised, the effect of the compositional discrepancy on provenance determinations is disputable, especially when the study focuses on a restricted particle size range. Fu et al. (2008) found that element concentrations were enriched in the finer fraction, but that this had no significant impact on the provenance determination, meaning that the fraction smaller than $63 \mu \mathrm{m}$ can be considered representative for suspended load.

Obviously linear mixing models yield the provenance information needed to study historical sediment fluxes. Quantitative determinations of the contributions of different sediment sources provide a means to elucidate the coupling between different geomorphic areas. As illustrated in the previous section, the response of different river systems to land use changes can be nicely unravelled with the use of linear mixing models (e.g. Figure 6 and 7). Whereas plots of tracers give a nice idea about the main sediment sources (e.g. Figure 10), they lack the quantitative output generated by linear mixing models. Qualitative approaches are nevertheless useful to explore a set of tracers before applying quantitative models.

\section{Concluding remarks}

The method of sediment fingerprinting is a powerful tool to obtain more detailed information on sediment sources and sinks in addition to historical sediment budgets. Especially when quantitative provenance information is incorporated in sediment budgets and modelling approaches, valuable information is gained on sediment dynamics. Depending on the floodplain typology of the river system in question, several tracer properties can be applied. It should however not be forgotten that the primary requirement is that spatially defined sources are sufficiently different from each other and that their spatial heterogeneity allows a good resolution of the fingerprint outcome. So far, the review only considered several tracer properties separately, it should be noted, however, that is often better to combine different 
This manuscript has been published as:

D'Haen K, Verstraeten G and Degryse P. 2012 Fingerprinting historical fluvial sediment fluxes. Progress in Physical Geography 36(2): 154-186.

sets of tracers. In this way, it is easier to detect the non-conservative behaviour of certain tracers.

There are, however, some limitations of historical provenance studies compared to contemporary studies. First, the temporal resolution of present day studies is usually much higher, mainly because a detailed chronology of floodplain deposits often cannot be established. Secondly, the spatial resolution of historical studies is limited when compared to contemporary research. The distinction of historical sediment sources is mainly based on differences in lithology and weathering, while radionuclides and biogeochemical tracers can also be used in present-day studies to distinguish areas under different land use. For historical time periods, information on historical land use patterns is often not available (e.g. Verstraeten et al., 2009a). Furthermore, the spatial resolution of contemporary studies can be increased by applying artificial tracers.

Moreover, the choice of tracers is often determined by the equipment present in an institution. This is one of the reasons why e.g. geochemical fingerprints are quite popular. Also, costeffectiveness issues can prohibit the use of particular methods.

\section{Acknowledgements}

This research is part of a project funded by the Belgian Program on Interuniversity Poles of Attraction (IUAP 6/22) initiated by the Belgian State, Prime Minister's Office, Science Policy Programming, along with support from the Concerted Action of the Flemish Government (GOA project nr. 3H051017). The support of the Center for Archaeological Science at the K.U. Leuven is also gratefully acknowledged. Moreover, the authors would like to thank two anonymous reviewers for their highly constructive criticism, which clearly improved the content as well as the presentation of this paper. 
This manuscript has been published as:

D'Haen K, Verstraeten G and Degryse P. 2012 Fingerprinting historical fluvial sediment fluxes. Progress in Physical Geography 36(2): 154-186.

\section{Figures}
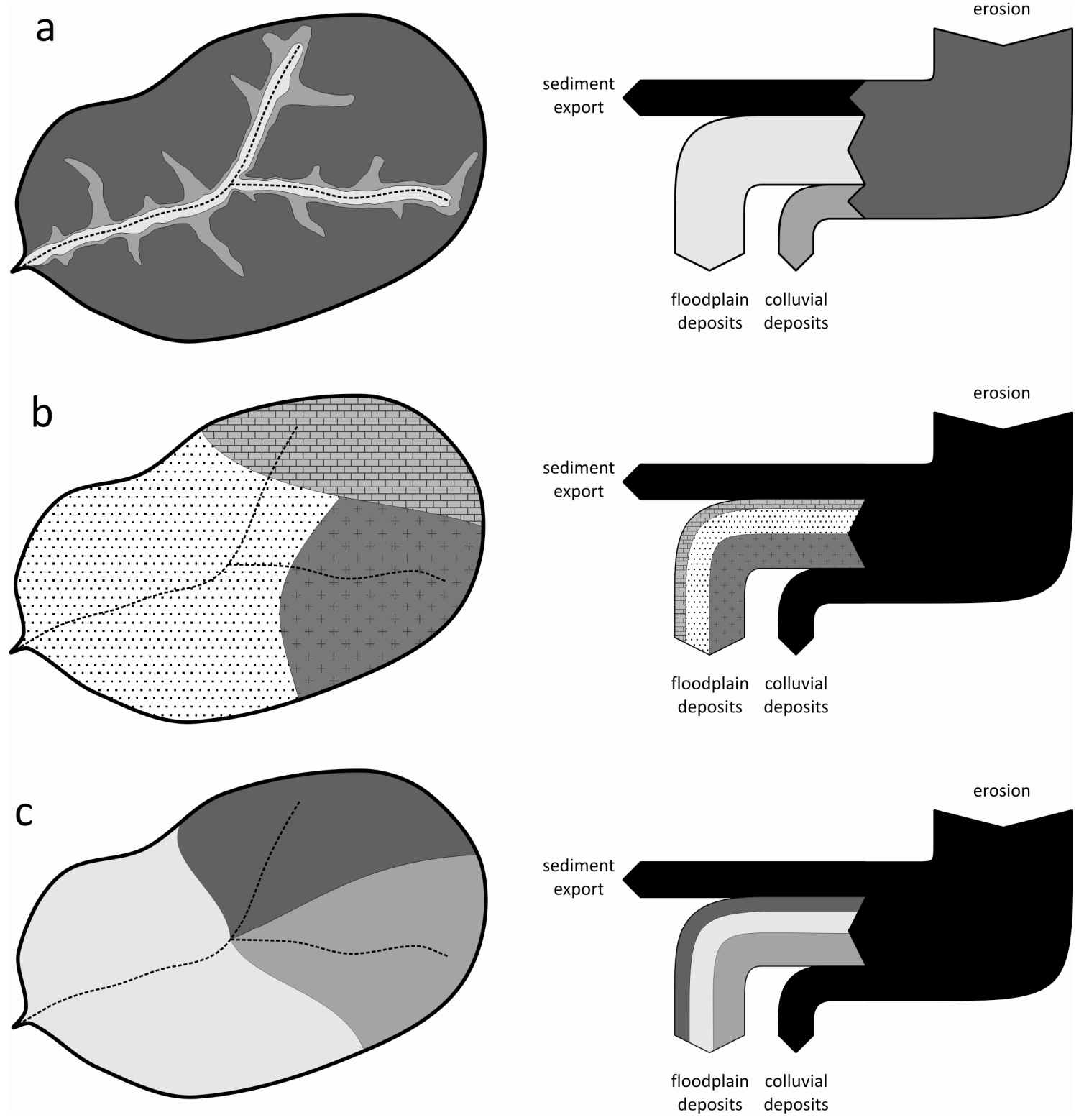

Figure 1 Conceptual catchment with: (a) regular sediment budget; (b) contributions of source areas to floodplain deposits as elucidated by fingerprinting; (c) contributions of tributaries to floodplain deposits as elucidated by fingerprinting 
This manuscript has been published as:

D'Haen K, Verstraeten G and Degryse P. 2012 Fingerprinting historical fluvial sediment fluxes. Progress in Physical Geography 36(2): 154-186.

Physical Properties

Clast lithological analysis

Colour

Grain size distribution

Grain morphology

Mineralogical Tracers

Bulk mineralogy

Heavy minerals

Clay minerals

Cathodoluminescence quartz

Mineral Magnetic Properties

$\chi_{L F}, \chi_{H F}, \chi_{F D}, A R M$

IRM, HIRM, ...

Geochemical Tracers

Major, trace elements

Composition minerals

Biogeochemical Tracers

$\mathrm{N}, \mathrm{C}, \mathrm{P}$

Fall-Out Radionuclides

${ }^{137} \mathrm{Cs},{ }^{210} \mathrm{~Pb},{ }^{7} \mathrm{Be}$

Cosmogenic Radionuclides ${ }^{10} \mathrm{Be},{ }^{26} \mathrm{Al}$

Isotopic Ratios

$\delta^{15} \mathrm{~N}, \delta^{13} \mathrm{C}$

$\varepsilon \mathrm{Nd}, \delta^{87} \mathrm{Sr},{ }^{206} \mathrm{~Pb} /{ }^{204} \mathrm{~Pb}, \ldots$

$\delta^{18} \mathrm{O}$ quartz

Mineral Ages

Zircon, monazite,

muscovite ages

Biogenic traders Pollen, diatoms,...

Artificial Tracers

Labelled clay, REE oxides, tagged bedload,...

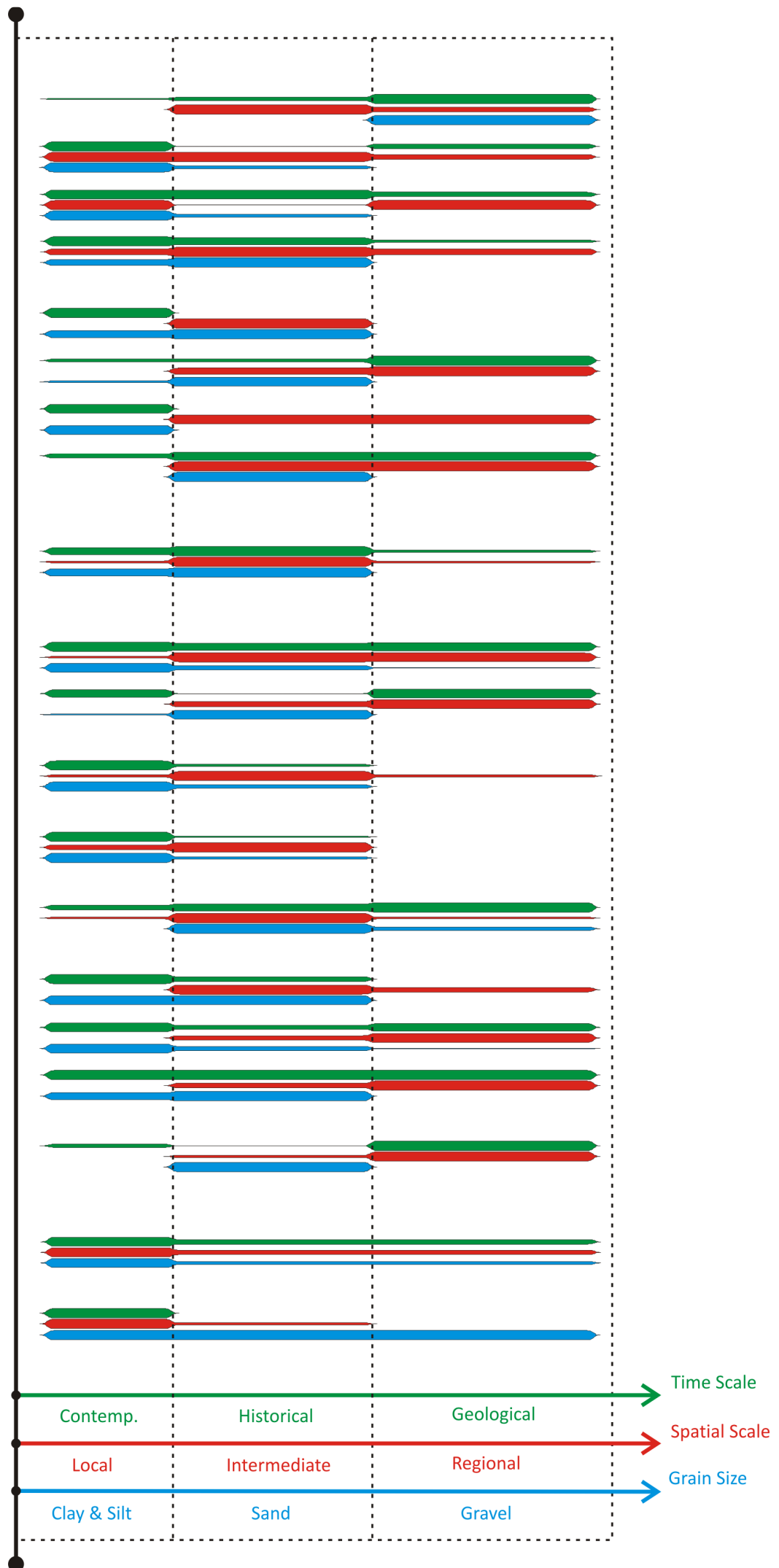


This manuscript has been published as:

D'Haen K, Verstraeten G and Degryse P. 2012 Fingerprinting historical fluvial sediment fluxes. Progress in Physical Geography 36(2): 154-186.

Figure 2 Overview of tracer properties considering their fields of application, the thickness of each bar is relative to the number of studies in each class.

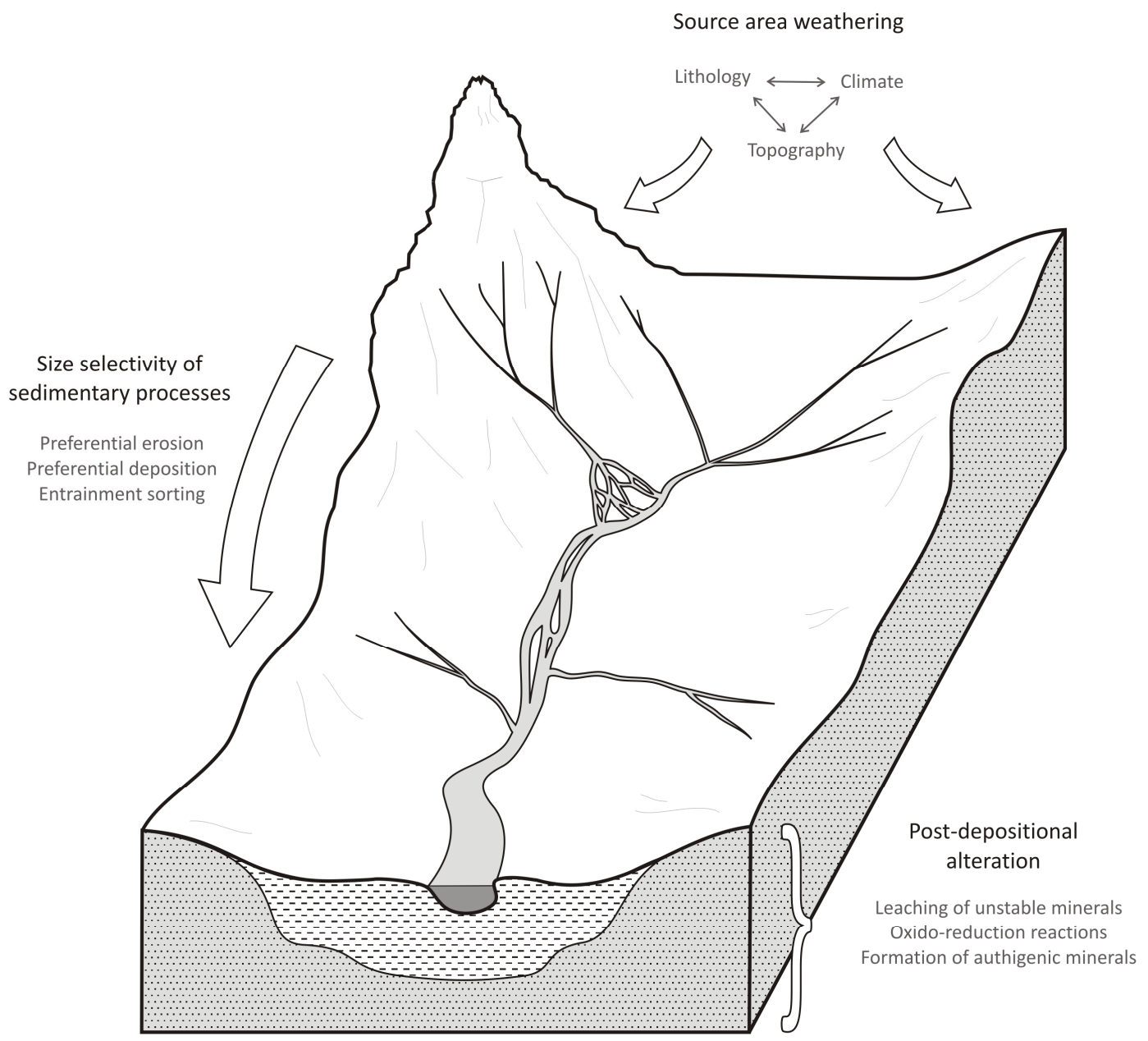

Figure 3 Processes affecting tracer properties from source to sink 
This manuscript has been published as:

D'Haen K, Verstraeten G and Degryse P. 2012 Fingerprinting historical fluvial sediment fluxes. Progress in Physical Geography 36(2): 154-186.

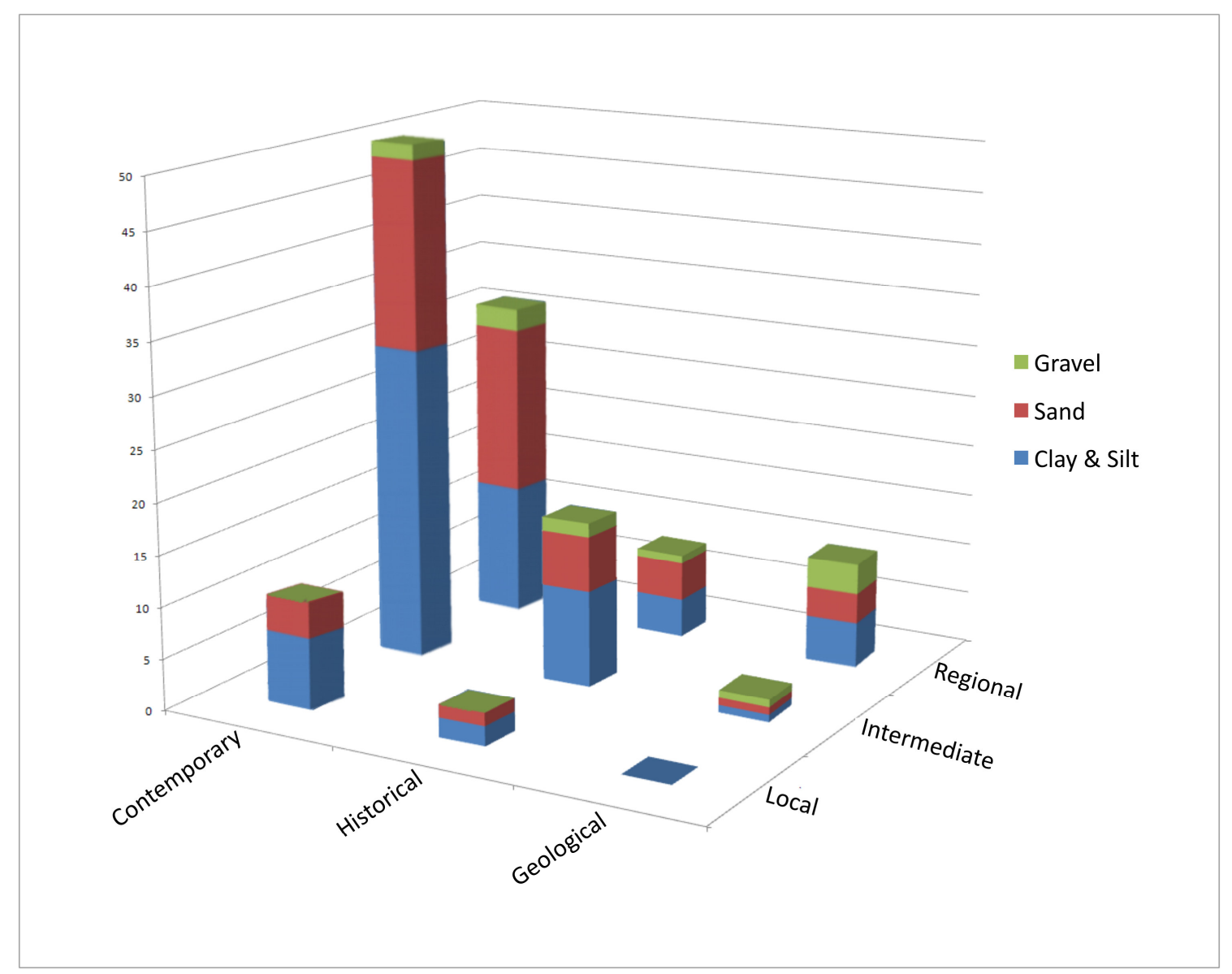

Figure 4 Number of studies in each temporal, spatial and grain size class (for details see text). 
This manuscript has been published as:

D'Haen K, Verstraeten G and Degryse P. 2012 Fingerprinting historical fluvial sediment fluxes. Progress in Physical Geography 36(2): 154-186.
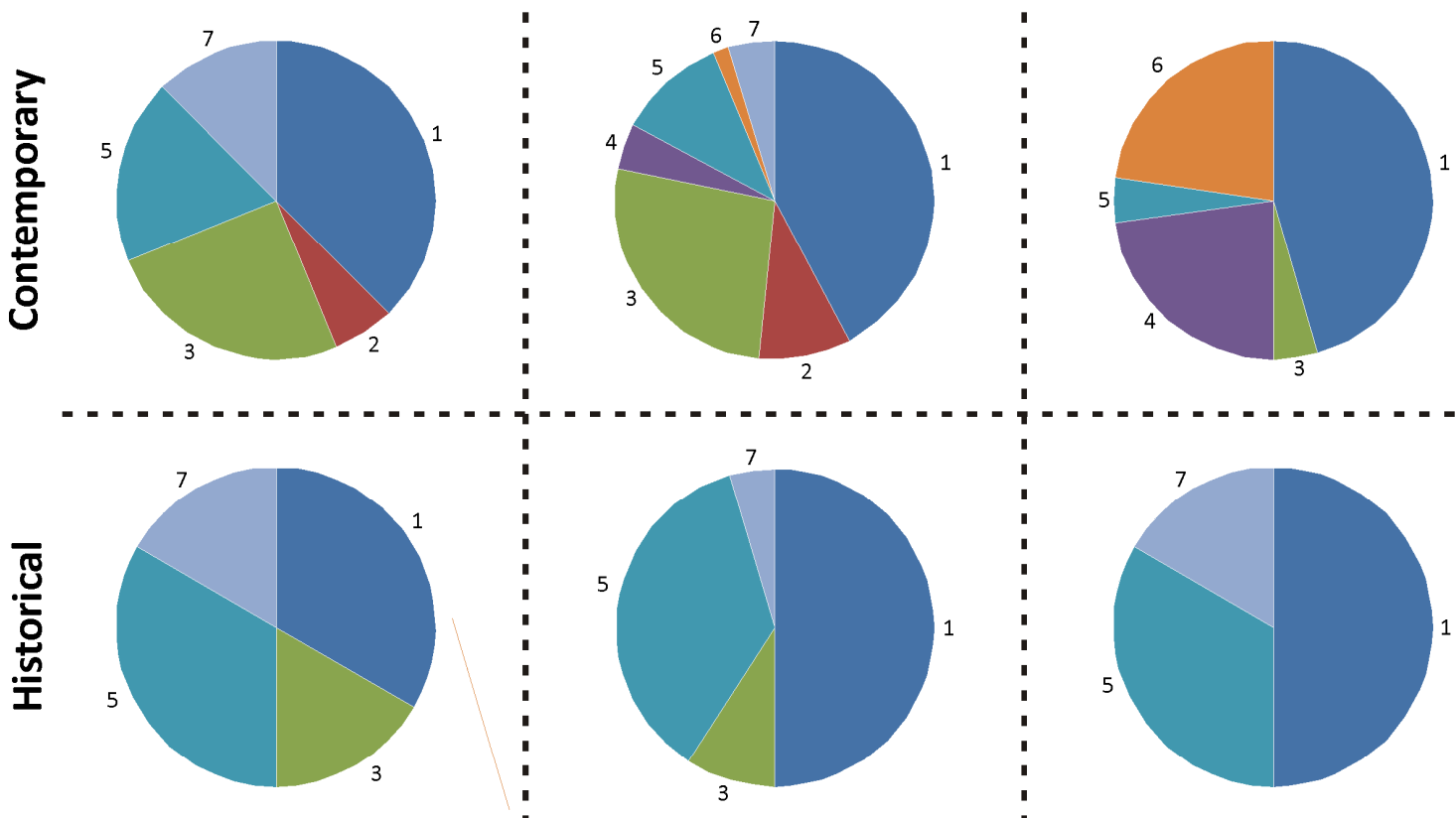

Local

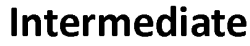

Regional

- 1 Geochemical tracers

3 Radionuclides

- 5 Mineral magnetic signal

" 7 Physical properties

- 2 Biogeochemical tracers

$\square 4$ Mineralogical tracers $\quad 6$ Isotope ratios

Figure 5 Tracers used to fingerprint fine grained alluvium in a number of settings, on contemporary and historical time scales and local to regional spatial scales. 
This manuscript has been published as:

D'Haen K, Verstraeten G and Degryse P. 2012 Fingerprinting historical fluvial sediment fluxes. Progress in Physical Geography 36(2): 154-186.
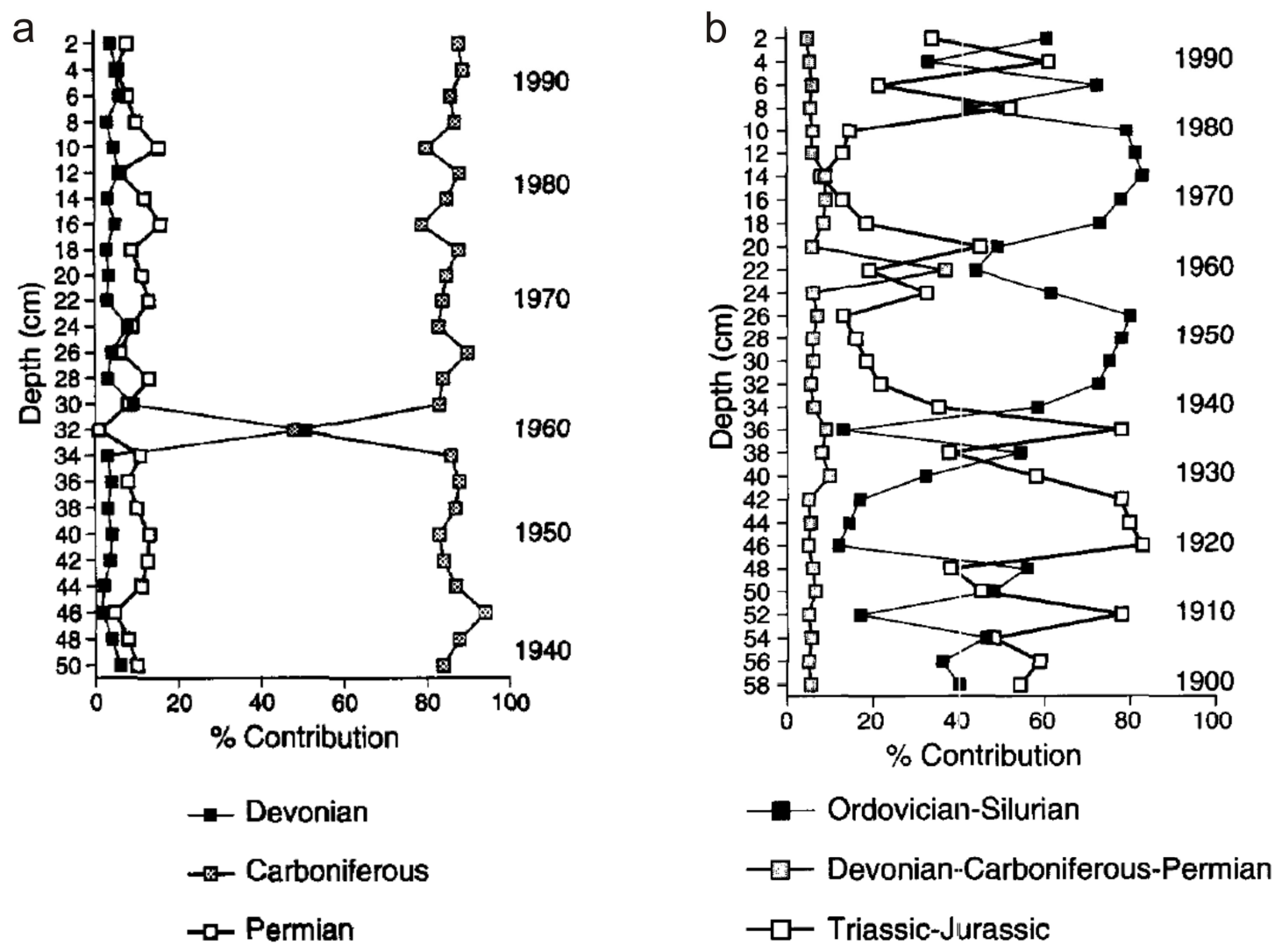

Figure 6 Results of the linear mixing model using geochemical fingerprints of the Exe (a) and Severn (b) catchments, UK (Collins et al., 1997b) 
This manuscript has been published as:

D'Haen K, Verstraeten G and Degryse P. 2012 Fingerprinting historical fluvial sediment fluxes. Progress in Physical Geography 36(2): 154-186.
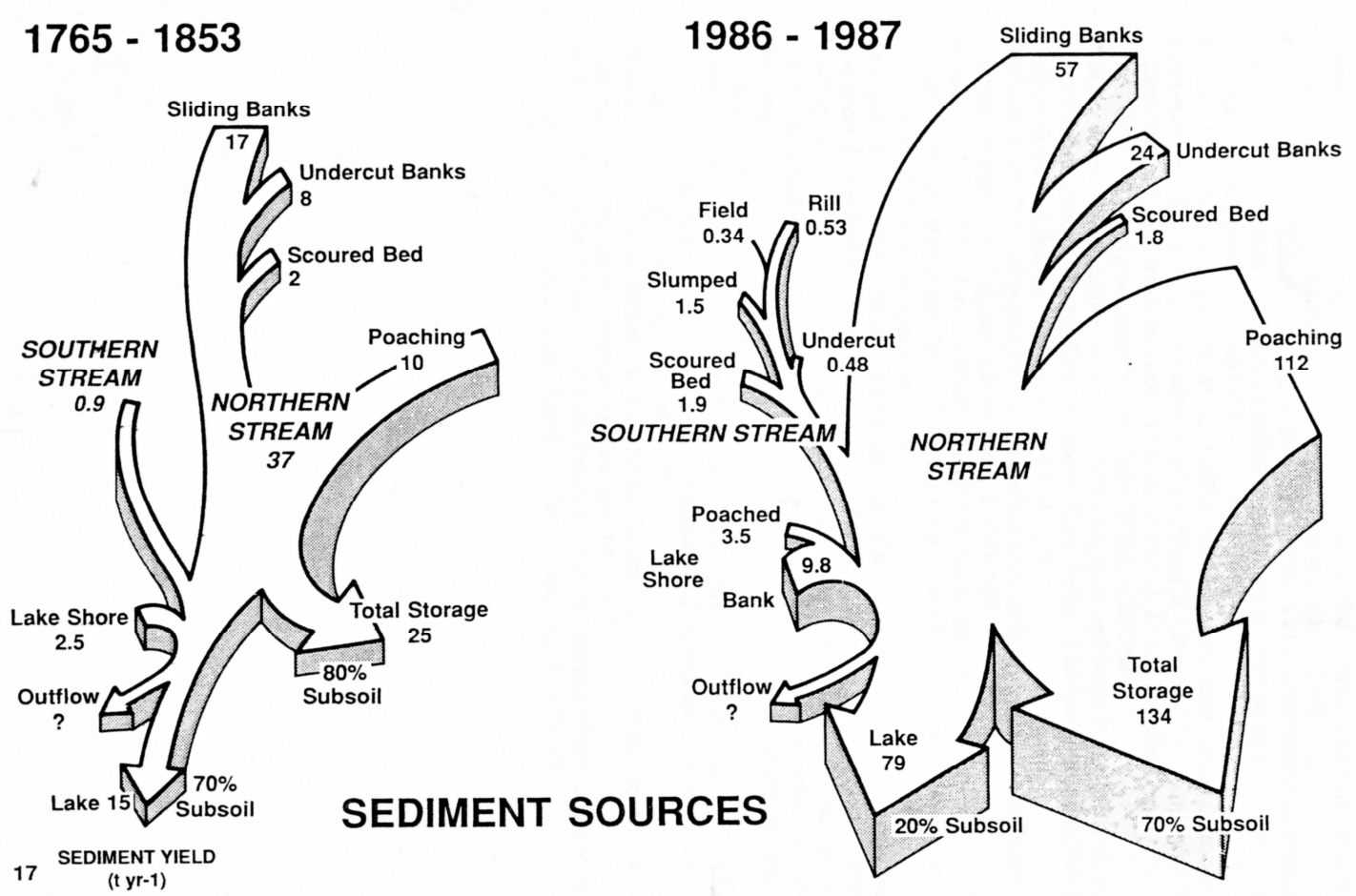

Figure 7 Integration of magnetic mixing models into sediment budgets to compare contemporary and historical sediment yields and sources of Seeswood catchment (Foster et al., 1990) 
This manuscript has been published as:

D'Haen K, Verstraeten G and Degryse P. 2012 Fingerprinting historical fluvial sediment fluxes. Progress in Physical Geography 36(2): 154-186.

a

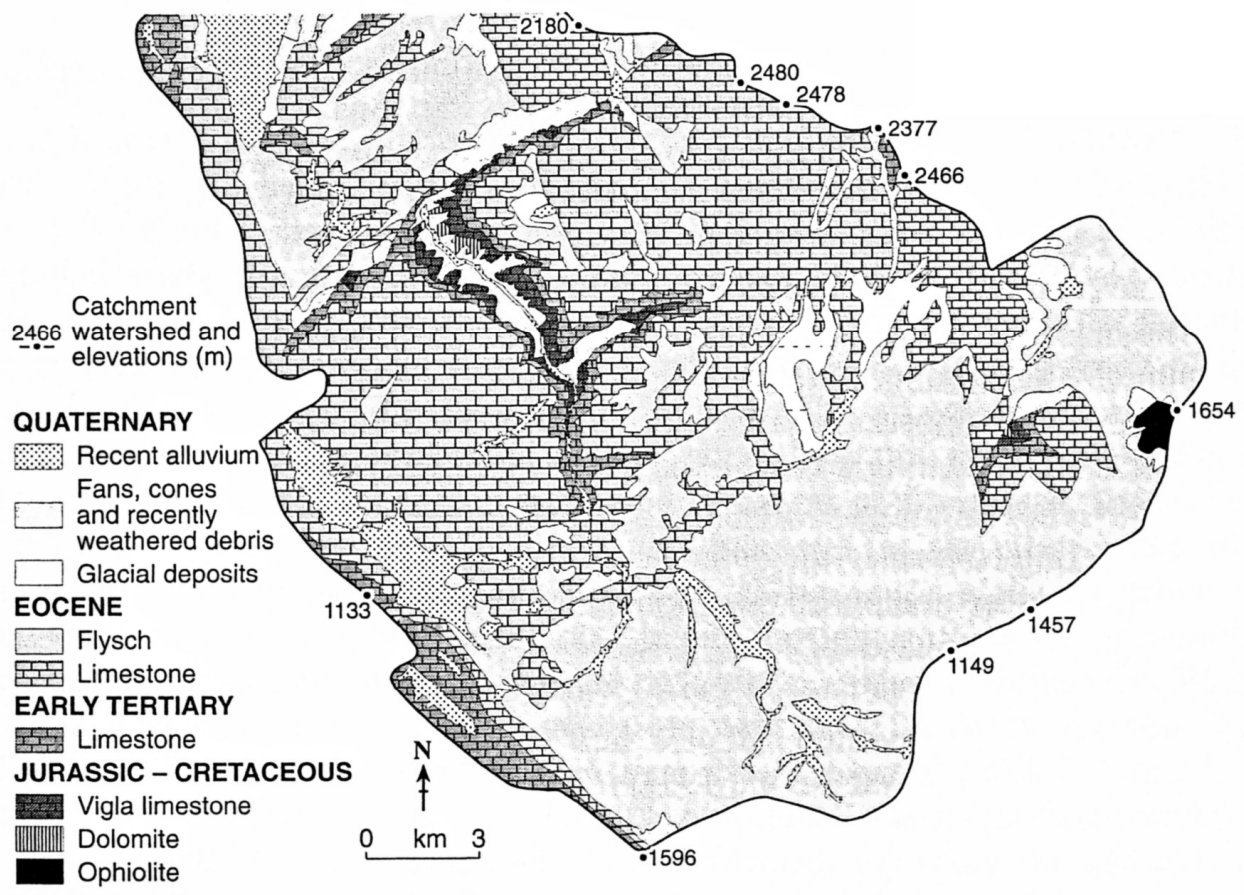

b

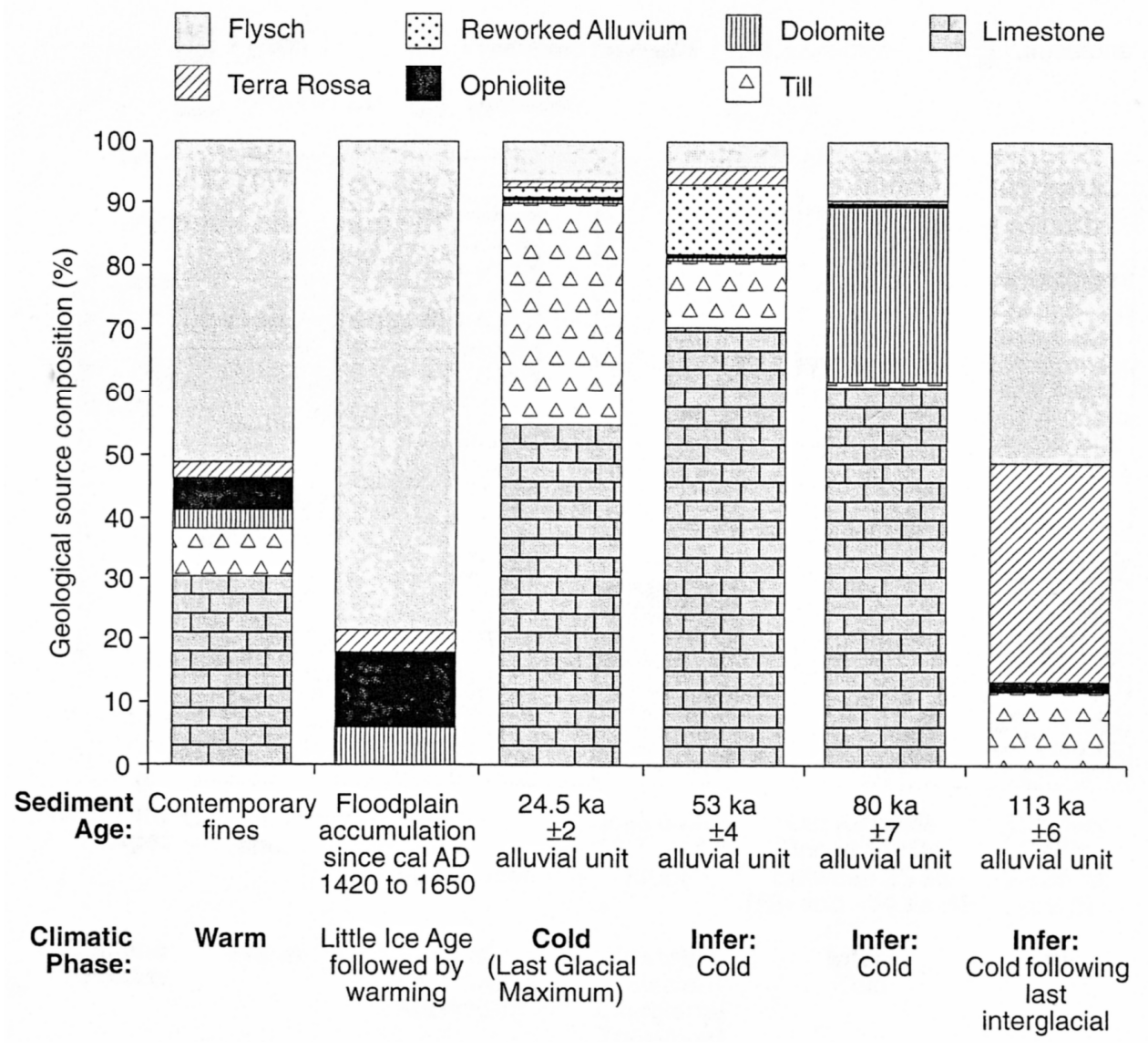


This manuscript has been published as:

D'Haen K, Verstraeten G and Degryse P. 2012 Fingerprinting historical fluvial sediment fluxes. Progress in Physical Geography 36(2): 154-186.

Figure 8 (a) Geological map of the Voidomatis catchment (b) Results of the linear mixing model of several alluvial units (Hamlin et al., 2000)

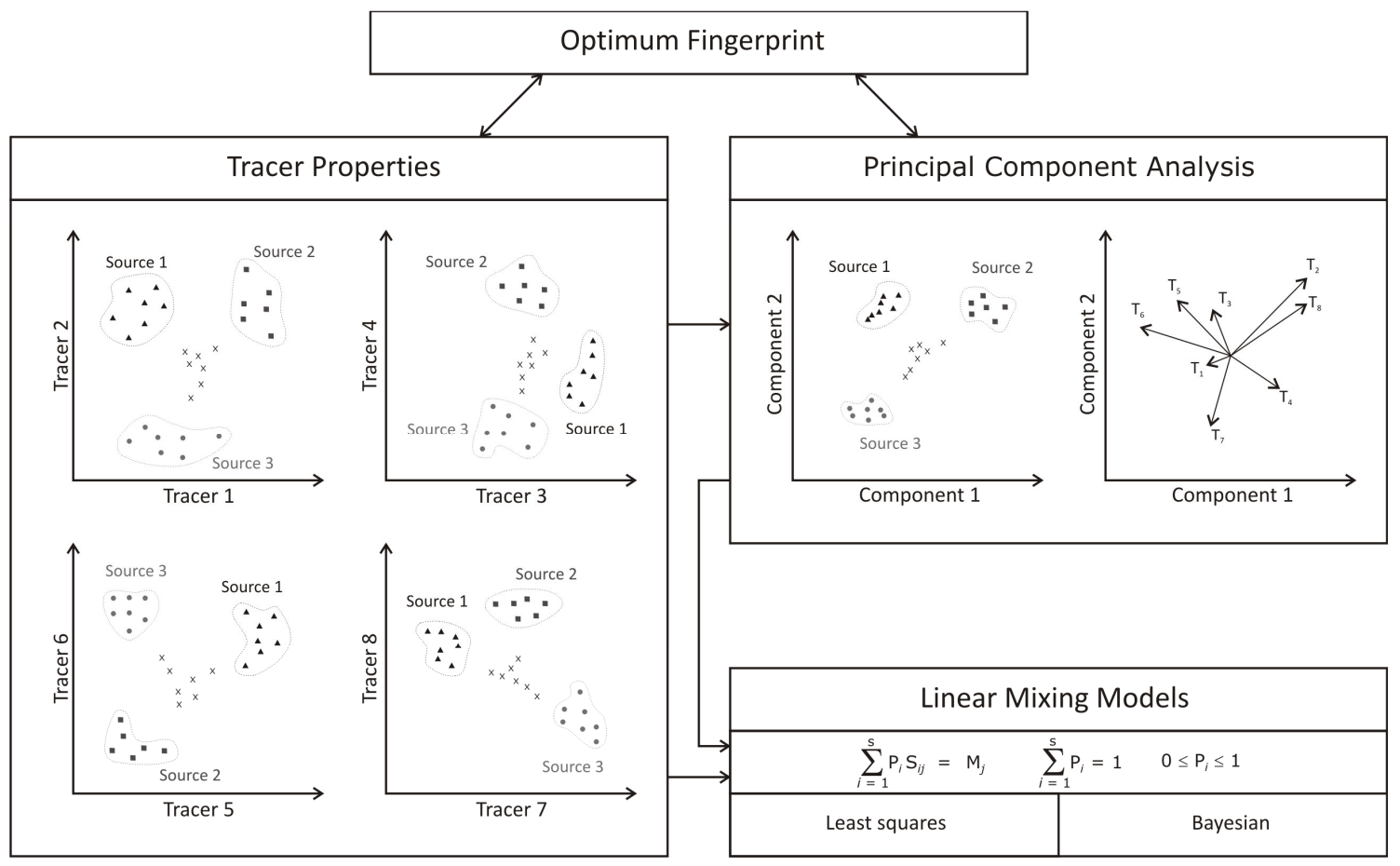

Figure 9 Overview of approaches used to gain provenance information from tracers 
This manuscript has been published as:

D'Haen K, Verstraeten G and Degryse P. 2012 Fingerprinting historical fluvial sediment fluxes. Progress in Physical Geography 36(2): 154-186.

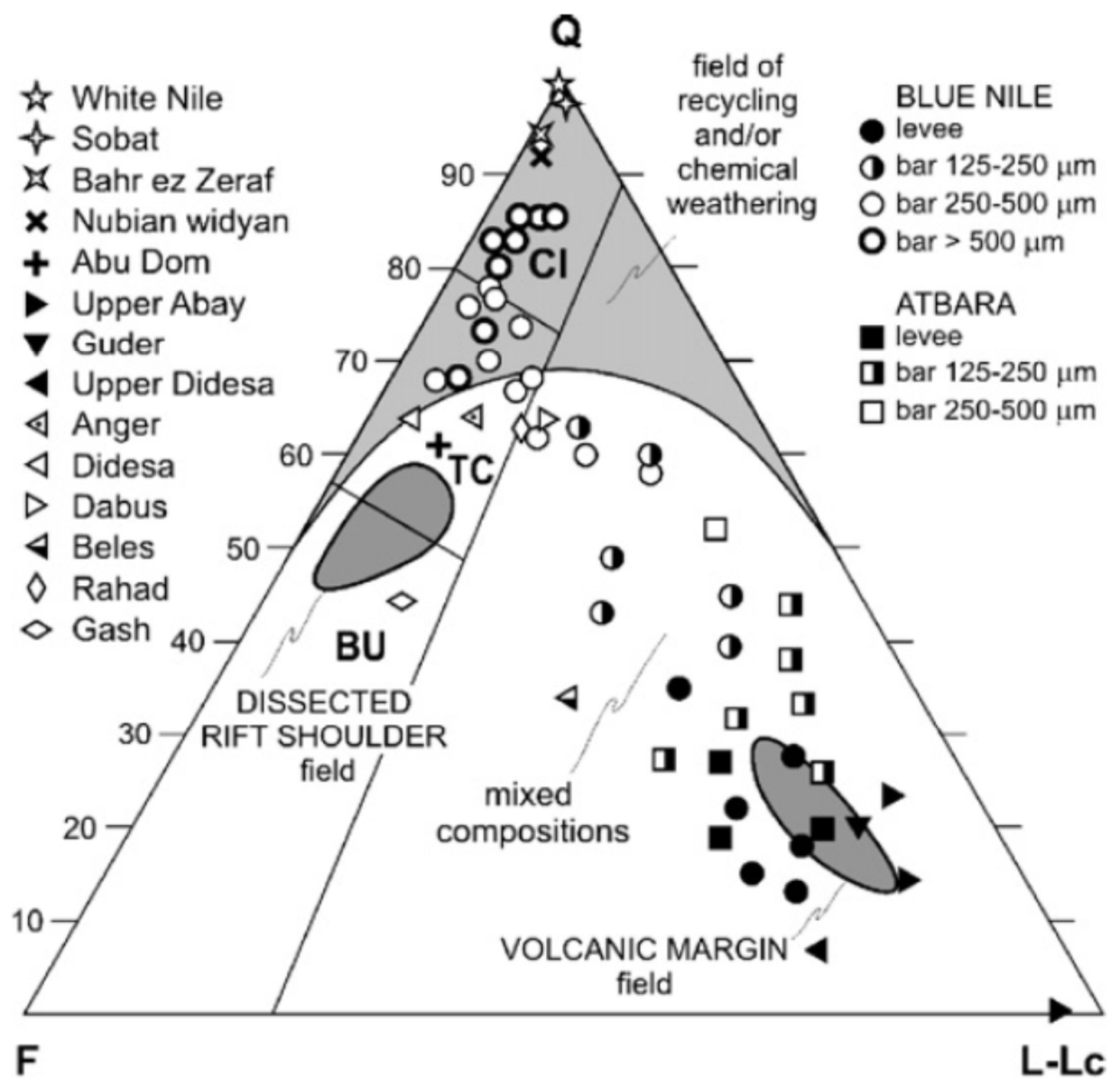

Figure 10 Ternary diagram showing the mineralogical composition of Nile river sands, $Q=$ quartz, $\mathrm{F}=$ feldspars, $\mathrm{L}-\mathrm{Lc}=$ non-carbonate lithic grains (Garzanti et al., 2006) 
This manuscript has been published as:

D'Haen K, Verstraeten G and Degryse P. 2012 Fingerprinting historical fluvial sediment fluxes. Progress in

Physical Geography 36(2): 154-186.

\section{References}

Abraham J, Allen PM, Dunbar JA and Dworkin SI. (1999) Sediment type distribution in reservoirs: sediment source versus morphometry. Environmental Geology 38: 101110.

Abu-Zeid MM, Baghdady AR and El-Etr HA. (2001) Textural attributes, mineralogy and provenance of sand dune fields in the greater Al Ain area, United Arab Emirates. Journal of Arid Environments 48: 475-499.

Aitchison J. (1986) Statistical analysis of compositional data New York: Chapman and Hall.

Aitchison J and Bacon-Shone J. (1999) Convex linear combinations of compositions. Biometrika 86: 351.

Aleon J, Chaussidon M, Marty B, Schutz L and Jaenicke R. (2002) Oxygen isotopes in single micrometer-sized quartz grains: Tracing the source of Saharan dust over long-distance atmospheric transport. Geochimica Et Cosmochimica Acta 66: 3351-3365.

Alt-Epping U, Stuut JBW, Hebbeln D and Schneider R. (2009) Variations in sediment provenance during the past 3000 years off the Tagus River, Portugal. Marine Geology 261: 82-91.

Amidon WH, Burbank DW and Gehrels GE. (2005) Construction of detrital mineral populations: insights from mixing of U-Pb zircon ages in Himalayan rivers. Basin Research 17: 463-485.

Amorosi A, Centineo MC, Dinelli E, Lucchini F and Tateo F. (2002) Geochemical and mineralogical variations as indicators of provenance changes in Late Quaternary deposits of SE Po Plain. Sedimentary Geology 151: 273-292.

Arribas J, Critelli S, Le Pera E and Tortosa A. (2000) Composition of modem stream sand derived from a mixture of sedimentary and metamorphic source rocks (Henares River, Central Spain). Sedimentary Geology 133: 27-48.

Barovich K and Hand M. (2008) Tectonic setting and provenance of the Paleoproterozoic Willyama Supergroup, Curnamona Province, Australia: Geochemical and Nd isotopic constraints on contrasting source terrain components. Precambrian Research 166: 318-337.

Basic F, Kisic I, Nestroy O, Mesic M and Butorac A. (2002) Particle size distribution (texture) of eroded soil material. Journal of Agronomy and Crop Science 188: 311322.

Basu A and Molinaroli E. (1991) Reliability and application of detrital opaque Fe-Ti oxide minerals in provenance determination. Geological Society, London, Special Publications 57: 55-65.

Belmont P, Pazzaglia FJ and Gosse JC. (2007) Cosmogenic Be-10 as a tracer for hillslope and channel sediment dynamics in the Clearwater River, western Washington State. Earth and Planetary Science Letters 264: 123-135.

Benedetti MM, Raber MJ, Smith MS and Leonard LA. (2006) Mineralogical indicators of alluvial sediment sources in the Cape Fear River basin, North Carolina. Physical Geography 27: 258-281.

Bentahila Y, Ben Othman D and Luck JM. (2008) Strontium, lead and zinc isotopes in marine cores as tracers of sedimentary provenance: A case study around Taiwan orogen. Chemical Geology 248: 62-82.

Bernet M and Bassett K. (2005) Provenance analysis by single-quartz-grain SEM-CL/optical microscopy. Journal of Sedimentary Research 75: 492-500. 
This manuscript has been published as:

D'Haen K, Verstraeten G and Degryse P. 2012 Fingerprinting historical fluvial sediment fluxes. Progress in

Physical Geography 36(2): 154-186.

Bernstein S, Frei D, McLimans RK, Knudsen C and Vasudev VN. (2008) Application of CCSEM to heavy mineral deposits: Source of high-Ti ilmenite sand deposits of South Kerala beaches, SW India. Journal of Geochemical Exploration 96: 25-42.

Beuselinck L, Govers G, Steegen A and Poesen J. (2000) Impact of soil aggregates on the size selectivity of the sediment deposition process. Role of Erosion and Sediment Transport in Nutrient and Contaminant Transfer, Proceedings: 99-107.

Billheimer D. (2001) Compositional receptor modeling. Environmetrics 12: 451-467.

Blake WH, Wallbrink PJ, Doerr SH, Shakesby RA and Humphreys GS. (2006) Magnetic enhancement in wildfire-affected soil and its potential for sediment-source ascription. Earth Surface Processes and Landforms 31: 249-264.

Boar RR and Harper DM. (2002) Magnetic susceptibilities of lake sediment and soils on the shoreline of Lake Naivasha, Kenya. Hydrobiologia 488: 81-88.

Boggs S, Kwon YI, Goles GG, Rusk BG, Krinsley D and Seyedolali A. (2002) Is quartz cathodoluminescence color a reliable provenance tool? A quantitative examination. Journal of Sedimentary Research 72: 408-415.

Borg LE and Banner JL. (1996) Neodymium and strontium isotopic constraints on soil sources in Barbados, West Indies. Geochimica Et Cosmochimica Acta 60: 4193-4206.

Bridgland DR. (1999) 'Wealden rivers' north of the Thames: a provenance study based on gravel clast analysis. Proceedings of the Geologists Association 110: 133-148.

Brown AG. (1985) The Potential Use of Pollen in the Identification of Suspended Sediment Sources. Earth Surface Processes and Landforms 10: 27-32.

Burke BC, Heimsath AM and White AF. (2007) Coupling chemical weathering with soil production across soil-mantled landscapes. Earth Surface Processes and Landforms 32: 853-873.

Caitcheon GG. (1998) The significance of various sediment magnetic mineral fractions for tracing sediment sources in Killimicat Creek. Catena 32: 131-142.

Cardona JPM, Mas JMG, Bellon AS, Domiinguez-Bella S and Lopez JM. (2005) Surface textures of heavy-mineral grains: a new contribution to provenance studies. Sedimentary Geology 174: 223-235.

Carpentier M, Chauvel C and Mattielli N. (2008) Pb-Nd isotopic constraints on sedimentary input into the Lesser Antilles arc system. Earth and Planetary Science Letters 272: 199-211.

Carter J, Owens PN, Walling DE and Leeks GJL. (2003) Fingerprinting suspended sediment sources in a large urban river system. Science of the Total Environment 314: 513-534.

Chappell J, Zheng HB and Fifield K. (2006) Yangtse River sediments and erosion rates from source to sink traced with cosmogenic Be-10: Sediments from major rivers. Palaeogeography Palaeoclimatology Palaeoecology 241: 79-94.

Charlesworth SM and Lees JA. (2001) The application of some mineral magnetic measurements and heavy metal analysis for characterising fine sediments in an urban catchment, Coventry, UK. Journal of Applied Geophysics 48: 113-125.

Chiverrell RC, Oldfield F, Appleby PG, Barlow D, Fisher E, Thompson R and Wolff G. (2008) Evidence for changes in Holocene sediment flux in Semer Water and Raydale, North Yorkshire, UK. Geomorphology 100: 70-82.

Clapp EM, Bierman PR and Caffee M. (2002) Using Be-10 and Al-26 to determine sediment generation rates and identify sediment source areas in an arid region drainage basin. Geomorphology 45: 89-104.

Collins A, Walling D and Leeks G. (1996) Composite fingerprinting of the spatial source of fluvial suspended sediment: a case study of the Exe and Severn River basins, United Kingdom. Géomorphologie: relief, processus, environnement 2: 41-53. 
This manuscript has been published as:

D'Haen K, Verstraeten G and Degryse P. 2012 Fingerprinting historical fluvial sediment fluxes. Progress in

Physical Geography 36(2): 154-186.

Collins AL and Walling DE. (2002) Selecting fingerprint properties for discriminating potential suspended sediment sources in river basins. Journal of Hydrology 261: 218244.

Collins AL and Walling DE. (2007) Sources of fine sediment recovered from the channel bed of lowland groundwater-fed catchments in the UK. Geomorphology 88: 120-138.

Collins AL, Walling DE and Leeks GJL. (1997a) Source type ascription for fluvial suspended sediment based on a quantitative composite fingerprinting technique. Catena 29: 1-27.

Collins AL, Walling DE and Leeks GJL. (1997b) Use of the geochemical record preserved in floodplain deposits to reconstruct recent changes in river basin sediment sources. Geomorphology 19: 151-167.

Collins AL, Walling DE and Leeks GJL. (1998) Use of composite fingerprints to determine the provenance of the contemporary suspended sediment load transported by rivers. Earth Surface Processes and Landforms 23: 31-52.

Collins AL, Walling DE, Webb L and King P. (2010a) Apportioning catchment scale sediment sources using a modified composite fingerprinting technique incorporating property weightings and prior information. Geoderma 155: 249-261.

Collins AL, Zhang Y, Walling DE and Black K. (2010b) Sourcing sediment loss to watercourses at catchment scale using a novel

tracing-tracking framework. Geophysical Research Abstracts 12

Damiani D and Giorgetti G. (2008) Provenance of glacial-marine sediments under the McMurdo/Ross Ice Shelf (Windless Bight, Antarctica): Heavy minerals and geochemical data. Palaeogeography Palaeoclimatology Palaeoecology 260: 262-283.

Dantas EL, de Alvarenga CJS, Santos RV and Pimentel MM. (2009) Using Nd isotopes to understand the provenance of sedimentary rocks from a continental margin to a foreland basin in the Neoproterozoic Paraguay Belt, Central Brazil. Precambrian Research 170: 1-12.

Davis CM and Fox JF. (2009) Sediment Fingerprinting: Review of the Method and Future Improvements for Allocating Nonpoint Source Pollution. Journal of Environmental Engineering-Asce 135: 490-504.

de Boer DH and Crosby G. (1995) Evaluating the Potential of Sem/Eds Analysis for Fingerprinting Suspended Sediment Derived from 2 Contrasting Topsoils. Catena 24: 243-258.

de Boer DH, Stone M and Levesque LMJ. (2000) Fractal dimensions of individual flocs and floc populations in streams. Hydrological Processes 14: 653-667.

de Mahiques MM, Tassinari CCG, Marcolini S, Violante RA, Figueira RCL, da Silveira ICA, Burone L and Sousa SHD. (2008) Nd and Pb isotope signatures on the Southeastern South American upper margin: Implications for sediment transport and source rocks. Marine Geology 250: 51-63.

Dearing JA. (2000) Natural magnetic tracers in fluvial geomorphology. In: Foster IDL (ed) Tracers in Geomorphology. Chichester: John Wiley \& Sons, Ltd, 57-82.

Dearing JA, Hu YQ, Doody P, James PA and Brauer A. (2001) Preliminary reconstruction of sediment-source linkages for the past 6000 yrs at the Petit Lac d'Annecy, France, based on mineral magnetic data. Journal of Paleolimnology 25: 245-258.

Decou A, Mamani M, von Eynatten H and Wörner G. (2009) Geochemical and thermochronological signals in Tertiary to Recent sediments from the Western Andes $\left(15-19^{\circ} \mathrm{S}\right)$ : proxies for sediment provenance and Andean uplift. Geophysical Research Abstracts 11

Dietrich WE. (1982) Settling Velocity of Natural Particles. Water Resources Research 18: 1615-1626. 
This manuscript has been published as:

D'Haen K, Verstraeten G and Degryse P. 2012 Fingerprinting historical fluvial sediment fluxes. Progress in

Physical Geography 36(2): 154-186.

Dill HG. (1998) A review of heavy minerals in clastic sediments with case studies from the alluvial-fan through the nearshore-marine environments. Earth-Science Reviews 45: 103-132.

Dinis PA and Soares AF. (2007) Stable and ultrastable heavy minerals of alluvial to nearshore marine sediments from Central Portugal: Facies related trends. Sedimentary Geology 201: 1-20.

Douglas GB, Gray CM, Hart BT and Beckett R. (1995) A Strontium Isotopic Investigation of the Origin of Suspended Particulate Matter (Spm) in the Murray-Darling River System, Australia. Geochimica Et Cosmochimica Acta 59: 3799-3815.

Duck RW, Rowan JS, Jenkins PA and Youngs I. (2001) A multi-method study of bedload provenance and transport pathways in an estuarine channel. Physics and Chemistry of the Earth Part B-Hydrology Oceans and Atmosphere 26: 747-752.

Dunai T. (2010) Cosmogenic Nuclides: Principles, Concepts and Applications in the Earth Surface Sciences, Cambridge: Cambridge University Press.

Dusar B, Verstraeten G, Notebaert B and Bakker J. (2011) Holocene environmental change and its impact on sediment dynamics in the Eastern Mediterranean. Earth Science Reviews In press.

Dutta PK. (1998) Provenance of chert in the Permo-Triassic Sydney Basin, Australia: oxygen isotopic evidence. Sedimentary Geology 117: 123-132.

Eberl D. (2004a) Quantitative mineralogy of the Yukon River system: Changes with reach and season, and determining sediment provenance. American Mineralogist 89: 1784.

Eberl DD. (2004b) Quantitative mineralogy of the Yukon River system: Changes with reach and season, and determining sediment provenance. American Mineralogist 89: 17841794.

Ergin M, Keskin S, Dogan AU, Kadioglu YK and Karakas Z. (2007) Grain size and heavy mineral distribution as related to hinterland and environmental conditions for modern beach sediments from the Gulfs of Antalya and Finike, eastern Mediterranean. Marine Geology 240: 185-196.

Everitt BS and Dunn G. (2001) Applied multivariate data analysis, London: Arnold.

Evrard O, Navratil O, Ayrault S, Ahmadi M, Nemery J, Legout C, Lefevre I, Poirel A, Bonte $\mathrm{P}$ and Esteves M. (2011) Combining suspended sediment monitoring and fingerprinting to determine the spatial origin of fine sediment in a mountainous river catchment. Earth Surface Processes and Landforms 36: 1072-1089.

Evrard O, Nemery J, Gratiot N, Duvert C, Ayrault S, Lefevre I, Poulenard J, Prat C, Bonte P and Esteves M. (2010) Sediment dynamics during the rainy season in tropical highland catchments of central Mexico using fallout radionuclides. Geomorphology 124: $42-54$.

Farmer GL, Barber D and Andrews J. (2003) Provenance of Late Quaternary ice-proximal sediments in the North Atlantic: Nd, Sr and Pb isotopic evidence. Earth and Planetary Science Letters 209: 227-243.

Filzmoser P, Hron K and Reimann C. (2009) Principal component analysis for compositional data with outliers. Environmetrics 20: 621-632.

Foster I, Grew R, Dearing J, Boardman J, Foster I and Dearing J. (1990) Magnitude and frequency of sediment transport in agricultural catchments: a paired lake-catchment study in Midland England. British Geomorphological Research Group Symposia Series

Foster I and Lees J. (1999) Changes in the physical and geochemical properties of suspended sediment delivered to the headwaters of LOIS river basins over the last 100 years: a 
This manuscript has been published as:

D'Haen K, Verstraeten G and Degryse P. 2012 Fingerprinting historical fluvial sediment fluxes. Progress in

Physical Geography 36(2): 154-186.

preliminary analysis of lake and reservoir bottom sediments. Hydrological Processes 13: 1067-1086.

Foster I and Lees J. (2000) Tracers in Geomorphology: Theory and Applications in Tracing Fine Particulate Sediments. In: Foster IDL (ed) Tracers in Geomorphology. Chichester: John Wiley \& Sons, Ltd, 3-20.

Foster IDL, Boardman J and Keay-Bright J. (2007) Sediment tracing and environmental history for two small catchments, Karoo Uplands, South Africa. Geomorphology 90: 126-143.

Foster IDL, Lees JA, Owens PN and Walling DE. (1998) Mineral magnetic characterization of sediment sources from an analysis of lake and floodplain sediments in the catchments of the Old Mill Reservoir and Slapton Ley, South Devon, UK. Earth Surface Processes and Landforms 23: 685-703.

Foster IDL, Mighall TM, Proffitt H, Walling DE and Owens PN. (2006) Post-depositional Cs137 mobility in the sediments of three shallow coastal lagoons, SW England. Journal of Paleolimnology 35: 881-895.

Foster IDL, Oldfield F, Flower RJ and Keatings K. (2008) Mineral magnetic signatures in a long core from Lake Qarun, Middle Egypt. Journal of Paleolimnology 40: 835-849.

Fox JF and Papanicolaou AN. (2008a) Application of the spatial distribution of nitrogen stable isotopes for sediment tracing at the watershed scale. Journal of Hydrology 358: 46-55.

Fox JF and Papanicolaou AN. (2008b) An un-mixing model to study watershed erosion processes. Advances in Water Resources 31: 96-108.

Fralick P and Kronberg B. (1997) Geochemical discrimination of clastic sedimentary rock sources. Sedimentary Geology 113: 111-124.

Frings RM. (2008) Downstream fining in large sand-bed rivers. Earth-Science Reviews 87: 39-60.

Fryirs K and Brierley GJ. (1999) Slope-channel decoupling in Wolumla catchment, New South Wales, Australia: the changing nature of sediment sources following European settlement. Catena 35: 41-63.

Fu B, Field JJ and Newham LTH. (2006) Tracing the source of sediment in Australian coastal catchments.

$\mathrm{Fu}$ B, Newham L and Field J. (2008) Influence of particle size on geochemical suspended sediment tracing in Australia. IAHS-AISH publication: 23-30.

Garcia D, Ravenne C, Marechal B and Moutte J. (2004) Geochemical variability induced by entrainment sorting: quantified signals for provenance analysis. Sedimentary Geology 171: 113-128.

Garzanti E, Ando S and Vezzoli G. (2008) Settling equivalence of detrital minerals and grainsize dependence of sediment composition. Earth and Planetary Science Letters 273: 138-151.

Garzanti E, Ando S and Vezzoli G. (2009) Grain-size dependence of sediment composition and environmental bias in provenance studies. Earth and Planetary Science Letters 277: 422-432.

Garzanti E, Ando S, Vezzoli G, Megid AAA and El Kammar A. (2006) Petrology of Nile River sands (Ethiopia and Sudan): Sediment budgets and erosion patterns. Earth and Planetary Science Letters 252: 327-341.

Garzanti E, Vezzoli G, Ando S, Lave J, Attal M, France-Lanord C and DeCelles P. (2007) Quantifying sand provenance and erosion (Marsyandi River, Nepal Himalaya). Earth and Planetary Science Letters 258: 500-515. 
This manuscript has been published as:

D'Haen K, Verstraeten G and Degryse P. 2012 Fingerprinting historical fluvial sediment fluxes. Progress in

Physical Geography 36(2): 154-186.

Ghilardi M, Kunesch S, Styllas M and Fouache E. (2008) Reconstruction of Mid-Holocene sedimentary environments in the central part of the Thessaloniki Plain (Greece), based on microfaunal identification, magnetic susceptibility and grain-size analyses. Geomorphology 97: 617-630.

Gingele FX and De Deckker P. (2005) Clay mineral, geochemical and Sr-Nd isotopic fingerprinting of sediments in the Murray-Darling fluvial system, southeast Australia. Australian Journal of Earth Sciences 52: 965-974.

Giosan L, Flood RD, Grutzner J and Mudie P. (2002) Paleoceanographic significance of sediment color on western North Atlantic drifts: II. Late Pliocene-Pleistocene sedimentation. Marine Geology 189: 43-61.

Gleason JD, Finney SC, Peralta SH, Gehrels GE and Marsaglia KM. (2007) Zircon and whole-rock $\mathrm{Nd}-\mathrm{Pb}$ isotopic Provenance of middle and upper Ordovician siliciclastic rocks, Argentine Precordillera. Sedimentology 54: 107-136.

Gotte T and Richter DK. (2006) Cathodoluminescence characterization of quartz particles in mature arenites. Sedimentology 53: 1347-1359.

Gotze J, Plotze M and Habermann D. (2001) Origin, spectral characteristics and practical applications of the cathodolumimescence (CL) of quartz - a review. Mineralogy and Petrology 71: 225-250.

Goudie A. (2006) The human impact on the natural environment: past, present, and future, Oxford: Blackwell Publishing.

Grigsby JD. (1990) Detrital Magnetite as a Provenance Indicator. Journal of Sedimentary Petrology 60: 940-951.

Grigsby JD. (1992) Chemical Fingerprinting in Detrital Ilmenite - a Viable Alternative in Provenance Research. Journal of Sedimentary Petrology 62: 331-337.

Grimes CB, John BE, Kelermen PB, Mazdab FK, Wooden JL, Cheadle MJ, Hanghoj K and Schwartz JJ. (2007) Trace element chemistry of zircons from oceanic crust: A method for distinguishing detrital zircon provenance. Geology 35: 643-646.

Grimshaw DL and Lewin J. (1980) Source Identification for Suspended Sediments. Journal of Hydrology 47: 151-162.

Grousset FE and Biscaye PE. (2005) Tracing dust sources and transport patterns using Sr, Nd and $\mathrm{Pb}$ isotopes. Chemical Geology 222: 149-167.

Gruszowski KE, Foster IDL, Lees JA and Charlesworth SM. (2003) Sediment sources and transport pathways in a rural catchment, Herefordshire, UK. Hydrological Processes 17: 2665-2681.

Hair JF, Black WC, Babin BJ, Anderson RE and Tatham RL. (1998) Multivariate data analysis: Prentice hall Upper Saddle River, NJ.

Hallsworth CR and Chisholm JI. (2008) Provenance of late Carboniferous sandstones in the Pennine Basin (UK) from combined heavy mineral, garnet geochemistry and palaeocurrent studies. Sedimentary Geology 203: 196-212.

Hamlin R, Woodward J, Black S and Macklin M. (2000) Sediment fingerprinting as a tool for interpreting long-term river activity: the Voidomatis Basin, North-west Greece. In: Foster IDL (ed) Tracers in Geomorphology. Chichester: John Wiley \& Sons Ltd, 473502.

Hardy F, Bariteau L, Lorrain S, Theriault I, Gagnon G, Messier D and Rougerie JF. (2010) Geochemical tracing and spatial evolution of the sediment bed load of the Romaine River, Quebec, Canada. Catena 81: 66-76.

Hasholt B. (1988) On identification of sources of sediment transport in small basins with special reference to particulate phosphorus. IAHS Publ 
This manuscript has been published as:

D'Haen K, Verstraeten G and Degryse P. 2012 Fingerprinting historical fluvial sediment fluxes. Progress in

Physical Geography 36(2): 154-186.

Haslett S, Bryant E and Curr R. (2000) Tracing beach sand provenance and transport using foraminifera: Preliminary example from northwest Europe and southeast Australia. In: Foster IDL (ed) Tracers in Geomorphology. Chichester: John Wiley \& Sons, Ltd, 437-452.

Hassan M and Ergenzinger P. (2003) Use of tracers in fluvial geomorphology. In: Kondolf G and Piegay H (eds) Tools in Fluvial Geomorphology. Chichester: John Wiley \& Sons, Ltd, 397-423.

Hatfield RG and Maher BA. (2008) Suspended sediment characterization and tracing using a magnetic fingerprinting technique: Bassenthwaite Lake, Cumbria, UK. Holocene 18: 105-115.

Hatfield RG and Maher BA. (2009) Fingerprinting upland sediment sources: particle sizespecific magnetic linkages between soils, lake sediments and suspended sediments. Earth Surface Processes and Landforms 34: 1359-1373.

Hatfield RG, Maher BA, Pates JM and Barker PA. (2008) Sediment dynamics in an upland temperate catchment: changing sediment sources, rates and deposition. Journal of Paleolimnology 40: 1143-1158.

Haughton PDW, Todd SP and Morton AC. (1991) Sedimentary provenance studies. Geological Society, London, Special Publications 57: 1-11.

He Q, Walling DE and Owens PN. (1996) Interpreting the Cs-137 profiles observed in several small lakes and reservoirs in southern England. Chemical Geology 129: 115-131.

Hesse PP. (1997) Mineral magnetic 'tracing' of aeolian dust in southwest Pacific sediments. Palaeogeography Palaeoclimatology Palaeoecology 131: 327-353.

Hillier S. (2001) Particulate composition and origin of suspended sediment in the R. Don, Aberdeenshire, UK. Science of the Total Environment 265: 281-293.

Hirner AV, Kritsotakis K and Tobschall HJ. (1990) Metal-Organic Associations in Sediments .1. Comparison of Unpolluted Recent and Ancient Sediments and Sediments Affected by Anthropogenic Pollution. Applied Geochemistry 5: 491-505.

Hoffmann T, Erkens G, Gerlach R, Klostermann J and Lang A. (2009) Trends and controls of Holocene floodplain sedimentation in the Rhine catchment. Catena 77: 96-106.

Honda M, Yabuki S and Shimizu H. (2004) Geochemical and isotopic studies of aeolian sediments in China. Sedimentology 51: 211-230.

Horowitz A and Elrick K. (1987) The relation of stream sediment surface area, grain size and composition to trace element chemistry. Applied Geochemistry 2: 437-451.

Hoskin PWO and Ireland TR. (2000) Rare earth element chemistry of zircon and its use as a provenance indicator. Geology 28: 627-630.

Hounslow MW and Morton AC. (2004) Evaluation of sediment provenance using magnetic mineral inclusions in clastic silicates: comparison with heavy mineral analysis. Sedimentary Geology 171: 13-36.

Il Lee Y. (2009) Geochemistry of shales of the Upper Cretaceous Hayang Group, SE Korea: Implications for provenance and source weathering at an active continental margin. Sedimentary Geology 215: 1-12.

Jahn BM, Gallet S and Han JM. (2001) Geochemistry of the Xining, Xifeng and Jixian sections, Loess Plateau of China: eolian dust provenance and paleosol evolution during the last $140 \mathrm{ka}$. Chemical Geology 178: 71-94.

Jenkins PA, Duck RW, Rowan JS and Walden J. (2002) Fingerprinting of bed sediment in the Tay Estuary, Scotland: an environmental magnetism approach. Hydrology and Earth System Sciences 6: 1007-1016. 
This manuscript has been published as:

D'Haen K, Verstraeten G and Degryse P. 2012 Fingerprinting historical fluvial sediment fluxes. Progress in

Physical Geography 36(2): 154-186.

Jin ZD, Li FC, Cao JJ, Wang SM and Yu JM. (2006) Geochemistry of Daihai Lake sediments, Inner Mongolia, north China: Implications for provenance, sedimentary sorting, and catchment weathering. Geomorphology 80: 147-163.

Joerin C, Beven K, Iorgulescu I and Musy A. (2002) Uncertainty in hydrograph separations based on geochemical mixing models. Journal of Hydrology 255: 90-106.

Jones AP. (2000) Late quaternary sediment sources, storage and transfers within mountain basins using clast lithological analysis: Pineta Basin, central Pyrenees, Spain. Geomorphology 34: 145-161.

Kasanzu C, Maboko MAH and Manya S. (2008) Geochemistry of fine-grained clastic sedimentary rocks of the Neoproterozoic Ikorongo Group, NE Tanzania: Implications for provenance and source rock weathering. Precambrian Research 164: 201-213.

Kimoto A, Nearing MA, Shipitalo MJ and Polyakov VO. (2006) Multi-year tracking of sediment sources in a small agricultural watershed using rare earth elements. Earth Surface Processes and Landforms 31: 1763-1774.

Kirkland CL, Pease V, Whitehouse MJ and Ineson JR. (2009) Provenance record from Mesoproterozoic-Cambrian sediments of Peary Land, North Greenland: Implications for the ice-covered Greenland Shield and Laurentian palaeogeography. Precambrian Research 170: 43-60.

Klassen RA. (2009) Geological controls on soil parent material geochemistry along a northern Manitoba-North Dakota transect. Applied Geochemistry 24: 1382-1393.

Kodama Y. (1994a) Downstream Changes in the Lithology and Grain-Size of Fluvial Gravels, the Watarase River, Japan - Evidence of the Role of Abrasion in Downstream Fining. Journal of Sedimentary Research Section a-Sedimentary Petrology and Processes 64: $68-75$.

Kodama Y. (1994b) Experimental-Study of Abrasion and Its Role in Producing Downstream Fining in Gravel-Bed Rivers. Journal of Sedimentary Research Section a-Sedimentary Petrology and Processes 64: 76-85.

Krause AK, Franks SW, Kalma JD, Loughran RJ and Rowan JS. (2003) Multi-parameter fingerprinting of sediment deposition in a small gullied catchment in SE Australia. Catena 53: 327-348.

Krein A, Petticrew E and Udelhoven T. (2003) The use of fine sediment fractal dimensions and colour to determine sediment sources in a small watershed. Catena 53: 165-179.

Krishnappan BG, Chambers PA, Benoy G and Culp J. (2009) Sediment source identification: a review and a case study in some Canadian streams. Canadian Journal of Civil Engineering 36: 1622-1633.

Kurashige Y and Fusejima Y. (1997) Source identification of suspended sediment from grainsize distributions: I. Application of nonparametric statistical tests. Catena 31: 39-52.

Le Pera E, Arribas J, Critelli S and Tortosa A. (2001) The effects of source rocks and chemical weathering on the petrogenesis of siliciclastic sand from the Neto River (Calabria, Italy): implications for provenance studies. Sedimentology 48: 357-378.

Lee SG, Kim JK, Yang DY and Kim JY. (2008) Rare earth element geochemistry and Nd isotope composition of stream sediments, south Han River drainage basin, Korea. Quaternary International 176: 121-134.

Lees JA. (1997) Mineral magnetic properties of mixtures of environmental and synthetic materials: linear additivity and interaction effects. Geophysical Journal International 131: 335-346.

Lees JA and Pethick JS. (1995) Problems associated with quantitative magnetic sourcing of sediments of the Scarborough to Mablethorpe coast, northeast England, UK. Earth Surface Processes and Landforms 20: 795-806. 
This manuscript has been published as:

D'Haen K, Verstraeten G and Degryse P. 2012 Fingerprinting historical fluvial sediment fluxes. Progress in

Physical Geography 36(2): 154-186.

Lindsey DA, Langer WH and Van Gosen BS. (2007) Using pebble lithology and roundness to interpret gravel provenance in piedmont fluvial systems of the Rocky Mountains, USA. Sedimentary Geology 199: 223-232.

Liu FJ, Parmenter R, Brooks PD, Conklin MH and Bales RC. (2008) Seasonal and interannual variation of streamflow pathways and biogeochemical implications in semi-arid, forested catchments in Valles Caldera, New Mexico. Ecohydrology 1: 239-252.

Liu H, Zhu RX and Li GX. (2003) Rock magnetic properties of the fine-grained sediment on the outer shelf of the East China Sea: implication for provenance. Marine Geology 193: 195-206.

Liu XM, Hesse P and Rolph T. (1999) Origin of maghaemite in Chinese loess deposits: aeolian or pedogenic? Physics of the Earth and Planetary Interiors 112: 191-201.

Lupker M, Aciego SM, Bourdon B, Schwander J and Stocker TF. (2010) Isotopic tracing (Sr, $\mathrm{Nd}, \mathrm{U}$ and $\mathrm{Hf}$ ) of continental and marine aerosols in an 18th century section of the Dye-3 ice core (Greenland). Earth and Planetary Science Letters 295: 277-286.

Mabit L, Benmansour M and Walling D. (2008) Comparative advantages and limitations of the fallout radionuclides $137 \mathrm{Cs}, 210 \mathrm{Pbex}$ and $7 \mathrm{Be}$ for assessing soil erosion and sedimentation. Journal of environmental radioactivity 99: 1799-1807.

Macklin MG and Lewin J. (2008) Alluvial responses to the changing Earth system. Earth Surface Processes and Landforms 33: 1374-1395.

Madhavaraju J, Barragan JCGY, Hussain SM and Mohan SP. (2009) Microtextures on quartz grains in the beach sediments of Puerto Penasco and Bahia Kino, Gulf of California, Sonora, Mexico. Revista Mexicana De Ciencias Geologicas 26: 367-379.

Maher BA, Watkins SJ, Brunskill G, Alexander J and Fielding CR. (2009) Sediment provenance in a tropical fluvial and marine context by magnetic 'fingerprinting' of transportable sand fractions. Sedimentology 56: 841-861.

Mahler BJ, Bennett PC and Zimmerman M. (1998a) Lanthanide-labeled clay: A new method for tracing sediment transport in karst. Ground Water 36: 835-843.

Mahler BJ, Winkler M, Bennett P and Hillis DM. (1998b) DNA-labeled clay: A sensitive new method for tracing particle transport. Geology 26: 831-834.

Martinez-Carreras N, Gallart F, Iffly J, Pfister L, Walling D and Krein A. (2008) Uncertainty assessment in suspended sediment fingerprinting based on tracer mixing models: a case study from Luxembourg. IAHS-AISH publication: 94-105.

Martinez-Carreras N, Udelhoven T, Krein A, Gallart F, Iffly JF, Ziebel J, Hoffmann L, Pfister L and Walling DE. (2010) The use of sediment colour measured by diffuse reflectance spectrometry to determine sediment sources: Application to the Attert River catchment (Luxembourg). Journal of Hydrology 382: 49-63.

Mazzullo J and Withers KD. (1984) Sources, distribution, and mixing of Late Pleistocene and Holocene sands of the South Texas continental shelf. Journal of Sedimentary Petrology 54: 1319-1334.

McConnachie JL and Petticrew EL. (2006) Tracing organic matter sources in riverine suspended sediment: Implications for fine sediment transfers. Geomorphology 79: 1326.

McDonnell M and Craw D. (2003) Stratigraphy and provenance of Pliocene greywackebearing conglomerate, Cardrona Valley, Otago, New Zealand. New Zealand Journal of Geology and Geophysics 46: 425-436.

Mclaren P. (1981) An Interpretation of Trends in Grain-Size Measures. Journal of Sedimentary Petrology 51: 611-624.

Mclaren P and Bowles D. (1985) The Effects of Sediment Transport on Grain-Size Distributions. Journal of Sedimentary Petrology 55: 457-470. 
This manuscript has been published as:

D'Haen K, Verstraeten G and Degryse P. 2012 Fingerprinting historical fluvial sediment fluxes. Progress in

Physical Geography 36(2): 154-186.

Messerli B, Grosjean M, Hofer T, Nunez L and Pfister C. (2000) From nature-dominated to human-dominated environmental changes. Quaternary Science Reviews 19: 459-479.

Miao XD, Lu HY, Li Z and Cao GC. (2008) Paleocurrent and fabric analyses of the imbricated fluvial gravel deposits in Huangshui Valley, the northeastern Tibetan Plateau, China. Geomorphology 99: 433-442.

Minella JPG, Walling DE and Merten GH. (2008) Combining sediment source tracing techniques with traditional monitoring to assess the impact of improved land management on catchment sediment yields. Journal of Hydrology 348: 546-563.

Mizota C, Faure K and Yamamoto M. (1996) Provenance of quartz in sedimentary mantles and laterites overlying bedrock in West Africa: Evidence from oxygen isotopes. Geoderma 72: 65-74.

Morton A, Fanning M and Milner P. (2008) Provenance characteristics of Scandinavian basement terrains: Constraints from detrital zircon ages in modern river sediments. Sedimentary Geology 210: 61-85.

Morton AC. (1991) Geochemical studies of detrital heavy minerals and their application to provenance research. Geological Society, London, Special Publications 57: 31-45.

Morton AC and Hallsworth CR. (1999) Processes controlling the composition of heavy mineral assemblages in sandstones. Sedimentary Geology 124: 3-29.

Motha JA, Wallbrink PJ, Hairsine PB and Grayson RB. (2002) Tracer properties of eroded sediment and source material. Hydrological Processes 16: 1983-2000.

Nagle GN and Ritchie JC. (2004) Wheat field erosion rates and channel bottom sediment sources in an intensively cropped northeastern oregon drainage basin. Land Degradation \& Development 15: 15-26.

Nakano T, Yokoo Y, Nishikawa M and Koyanagi H. (2004) Regional Sr-Nd isotopic ratios of soil minerals in northern China as Asian dust fingerprints. Atmospheric Environment 38: 3061-3067.

Nascimento MD, Goes AM, Macambira MJB and Brod JA. (2007) Provenance of Albian sandstones in the Sao Luis-Grajau Basin (northern Brazil) from evidence of $\mathrm{Pb}-\mathrm{Pb}$ zircon ages, mineral chemistry of tourmaline and palaeocurrent data. Sedimentary Geology 201: 21-42.

Neall VE, Stewart RB, Wallace RC, Williams MC and Mew G. (2001) Mineralogy, stratigraphy, and provenance of soil coverbeds in the Kumara district, Westland. New Zealand Journal of Geology and Geophysics 44: 205-218.

Nesbitt HW, Young GM, McLennan SM and Keays RR. (1996) Effects of chemical weathering and sorting on the petrogenesis of siliciclastic sediments, with implications for provenance studies. Journal of Geology 104: 525-542.

Nichols KK, Bierman PR, Hooke RL, Clapp EM and Caffee M. (2002) Quantifying sediment transport on desert piedmonts using Be-10 and Al-26. Geomorphology 45: 105-125.

Notebaert B, Verstraeten G, Rommens T, Vanmontfort B, Govers G and Poesen J. (2009) Establishing a Holocene sediment budget for the river Dijle. Catena 77: 150-163.

Ohta T. (2004) Geochemistry of Jurassic to earliest Cretaceous deposits in the Nagato Basin, SW Japan: implication of factor analysis to sorting effects and provenance signatures. Sedimentary Geology 171: 159-180.

Ohta T. (2008) Measuring and adjusting the weathering and hydraulic sorting effects for rigorous provenance analysis of sedimentary rocks: a case study from the Jurassic Ashikita Group, south-west Japan. Sedimentology 55: 1687-1701.

Oldfield F. (2007) Sources of fine-grained magnetic minerals in sediments: a problem revisited. Holocene 17: 1265-1271. 
This manuscript has been published as:

D'Haen K, Verstraeten G and Degryse P. 2012 Fingerprinting historical fluvial sediment fluxes. Progress in

Physical Geography 36(2): 154-186.

Oldfield F, Appleby PG and Van der Post KD. (1999) Problems of core correlation, sediment source ascription and yield estimation in Ponsonby Tarn, West Cumbria, UK. Earth Surface Processes and Landforms 24: 975-992.

Oldfield F and Crowther J. (2007) Establishing fire incidence in temperate soils using magnetic measurements. Palaeogeography Palaeoclimatology Palaeoecology 249: 362-369.

Oszczypko N and Salata D. (2005) Provenance analyses of the Late Cretaceous-Palaeocene deposits of the Magura Basin (Polish Western Carpathians) - evidence from a study of the heavy minerals. Acta Geologica Polonica 55: 237-267.

Owens PN and Walling DE. (2002) Changes in sediment sources and floodplain deposition rates in the catchment of the River Tweed, Scotland, over the last 100 years: The impact of climate and land use change. Earth Surface Processes and Landforms 27: 403-423.

Owens PN, Walling DE and Leeks GJL. (1999) Use of floodplain sediment cores to investigate recent historical changes in overbank sedimentation rates and sediment sources in the catchment of the River Ouse, Yorkshire, UK. Catena 36: 21-47.

Palmer MJ and Douglas GB. (2008) A Bayesian statistical model for end member analysis of sediment geochemistry, incorporating spatial dependences. Journal of the Royal Statistical Society Series C-Applied Statistics 57: 313-327.

Parsons AJ and Foster IDL. (2011) What can we learn about soil erosion from the use of ${ }^{137}$ Cs? Earth Science Reviews In press.

Perg LA, Anderson RS and Finkel RC. (2003) Use of cosmogenic radionuclides as a sediment tracer in the Santa Cruz littoral cell, California, United States. Geology 31: 299-302.

Piper DZ, Ludington S, Duval JS and Taylor HE. (2006) Geochemistry of bed and suspended sediment in the Mississippi river system: Provenance versus weathering and winnowing. Science of the Total Environment 362: 179-204.

Polyakov VO and Nearing MA. (2004) Rare earth element oxides for tracing sediment movement. Catena 55: 255-276.

Pope GA, Dorn RI and Dixon JC. (1995) A New Conceptual-Model for Understanding Geographical Variations in Weathering. Annals of the Association of American Geographers 85: 38-64.

Rahman MJJ and Suzuki S. (2007) Geochemistry of sandstones from the Miocene Surma Group, Bengal Basin, Bangladesh: Implications for provenance, tectonic setting and weathering. Geochemical Journal 41: 415-428.

Reimann C, Filzmoser P, Garrett R and Dutter R. (2008) Statistical Data Analysis Explained: Wiley Online Library.

Renner RM. (1993) The Resolution of a Compositional Data Set into Mixtures of Fixed Source Compositions. Applied Statistics-Journal of the Royal Statistical Society Series C 42: 615-631.

Revel-Rolland M, Arnaud F, Chapron E, Desmet M, Givelet N, Alibert C and McCulloch M. (2005) $\mathrm{Sr}$ and $\mathrm{Nd}$ isotopes as tracers of clastic sources in Lake Le Bourget sediment (NW Alps, France) during the Little Ice Age: Palaeohydrology implications. Chemical Geology 224: 183-200.

Reynolds PH, Pe-Piper G, Piper DJW and Grist AM. (2009) Single-grain detrital-muscovite ages from Lower Cretaceous sandstones, Scotian basin, and their implications for provenance. Bulletin of Canadian Petroleum Geology 57: 63-80.

Rhoton F, Emmerich W, DiCarlo D, McChesney D, Nearing M and Ritchie J. (2008) Identification of Suspended Sediment Sources Using Soil Characteristics in a Semiarid Watershed. 
This manuscript has been published as:

D'Haen K, Verstraeten G and Degryse P. 2012 Fingerprinting historical fluvial sediment fluxes. Progress in

Physical Geography 36(2): 154-186.

Rollinson H. (1993) Using geochemical data: evaluation, presentation, interpretation: Longman Harlow.

Rowan J, Goodwill P and Franks S. (2000) Uncertainty estimation in fingerprinting suspended sediment sources. In: Foster IDL (ed) Tracers in Geomorphology. Chichester: John Wiley \& Sons, Ltd, 279-290.

Roy PD, Caballero M, Lozano R and Smykatz-Klossd W. (2008) Geochemistry of late quaternary sediments from Tecocomulco lake, central Mexico: Implication to chemical weathering and provenance. Chemie Der Erde-Geochemistry 68: 383-393.

Russell MA, Walling DE and Hodgkinson RA. (2001) Suspended sediment sources in two small lowland agricultural catchments in the UK. Journal of Hydrology 252: 1-24.

Sabeen HM, Ramanujam N and Morton AC. (2002) The provenance of garnet: constraints provided by studies of coastal sediments from southern India. Sedimentary Geology 152: 279-287.

Sageman B and Lyons T. (2003) Geochemistry of fine-grained sediments and sedimentary rocks. Treatise on Geochemistry 7: 115-158.

Schwartz JJ and Gromet LP. (2004) Provenance of a late Proterozoic - early Cambrian basin, Sierras de Cordoba, Argentina. Precambrian Research 129: 1-21.

Sear D, Lee M, Oakey R, Carling P, Collins M and Foster I. (2000) Coarse sediment tracing technology in littoral and fluvial environments: a review. In: Foster IDL (ed) Tracers in Geomorphology. Chichester: John Wiley \& Sons, Ltd, 21-56.

Shen ZX, Bloemendal J, Mauz B, Chiverrell RC, Dearing JA, Lang A and Liu QS. (2008) Holocene environmental reconstruction of sediment-source linkages at Crummock Water, English Lake District, based on magnetic measurements. Holocene 18: 129140.

Singh P. (2009) Major, trace and REE geochemistry of the Ganga River sediments: Influence of provenance and sedimentary processes. Chemical Geology 266: 242-255.

Singh SK and France-Lanord C. (2002) Tracing the distribution of erosion in the Brahmaputra watershed from isotopic compositions of stream sediments. Earth and Planetary Science Letters 202: 645-662.

Small IF, Rowan JS and Franks SW. (2002) Quantitative sediment fingerprinting using a Bayesian uncertainty estimation framework. Structure, Function and Management Implications of Fluvial Sedimentary Systems: 443-450

484.

Stamoulis S, Gibbs RJ and Menon MG. (1996) Geochemical phases of metals in Hudson River estuary sediments. Environment International 22: 185-194.

Stone PM and Walling DE. (1997) Particle size selectivity considerations in suspended sediment budget investigations. Water Air and Soil Pollution 99: 63-70.

Stuut JBW, Prins MA, Schneider RR, Weltje GJ, Jansen JHF and Postma G. (2002) A 300kyr record of aridity and wind strength in southwestern Africa: inferences from grainsize distributions of sediments on Walvis Ridge, SE Atlantic. Marine Geology 180: 221-233.

Thomas CW and Aitchison J. (2005) Compositional data analysis of geological variability and process: A case study. Mathematical Geology 37: 753-772.

Thoms M, Brennan S and Franks S. (2008) The sources and dispersal of sediment within a large flood plain complex. IAHS-AISH publication: 52-59.

Tolosana-Delgado R and von Eynatten H. (2010) Simplifying compositional multiple regression: Application to grain size controls on sediment geochemistry. Computers \& Geosciences 36: 577-589. 
This manuscript has been published as:

D'Haen K, Verstraeten G and Degryse P. 2012 Fingerprinting historical fluvial sediment fluxes. Progress in

Physical Geography 36(2): 154-186.

Tutken T, Eisenhauer A, Wiegand B and Hansen BT. (2002) Glacial-interglacial cycles in Sr and $\mathrm{Nd}$ isotopic composition of Arctic marine sediments triggered by the Svalbard/Barents Sea ice sheet. Marine Geology 182: 351-372.

Van Oost K, Van Muysen W, Govers G, Deckers J and Quine TA. (2005) From water to tillage erosion dominated landform evolution. Geomorphology 72: 193-203.

Veevers JJ and Saeed A. (2007) Central Antarctic provenance of Permian sandstones in Dronning Maud Land and the Karoo Basin: Integration of U-Pb and T-DM ages and host-rock affinity from detrital zircons. Sedimentary Geology 202: 653-676.

Verstraeten G, Lang A and Houben P. (2009a) Human impact on sediment dynamics quantification and timing Introduction. Catena 77: 77-80.

Verstraeten G, Rommens T, Peeters I, Poesen J, Govers G and Lang A. (2009b) A temporarily changing Holocene sediment budget for a loess-covered catchment (central Belgium). Geomorphology 108: 24-34.

Vezzoli G, Garzanti E and Monguzzi S. (2004) Erosion in the Western Alps (Dora Baltea basin) - 1. Quantifying sediment provenance. Sedimentary Geology 171: 227-246.

Vologina EG, Kashik SA, Sturm M, Vorob'eva SS, Lomonosova TK, Kalashnikova IA, Khramtsova TI and Toshchakov SY. (2007) Results of research into Holocene sediments of the South and Central basins of Lake Baikal (BDP-97 and short cores). Russian Geology and Geophysics 48: 312-322.

von Eynatten H. (2004) Statistical modelling of compositional trends in sediments. Sedimentary Geology 171: 79-89.

von Eynatten H and Gaupp R. (1999) Provenance of Cretaceous synorogenic sandstones in the Eastern Alps: constraints from framework petrography, heavy mineral analysis and mineral chemistry. Sedimentary Geology 124: 81-111.

von Eynatten H, Pawlowsky-Glahn V and Egozcue JJ. (2002) Understanding perturbation on the simplex: A simple method to better visualize and interpret compositional data in ternary diagrams. Mathematical Geology 34: 249-257.

Walden J, Slattery MC and Burt TP. (1997) Use of mineral magnetic measurements to fingerprint suspended sediment sources: approaches and techniques for data analysis. Journal of Hydrology 202: 353-372.

Wallbrink P and Fogarty P. (1998) Sediment sourcing in the Lake Burley Griffin catchment. CSIRO Land and Water, Technical Report 30: 98.

Walling DE. (2005) Tracing suspended sediment sources in catchments and river systems. Science of the Total Environment 344: 159-184.

Walling DE, Collins AL, Sichingabula HM and Leeks GJL. (2001) Integrated assessment of catchment suspended sediment budgets: A Zambian example. Land Degradation \& Development 12: 387-415.

Walling DE and Moorehead PW. (1989) The Particle-Size Characteristics of Fluvial Suspended Sediment - an Overview. Hydrobiologia 176: 125-149.

Walling DE, Owens PN, Foster IDL and Lees JA. (2003) Changes in the fine sediment dynamics of the Ouse and Tweed basins in the UK over the last 100-150 years. Hydrological Processes 17: 3245-3269.

Walling DE, Owens PN and Leeks GJL. (1999) Fingerprinting suspended sediment sources in the catchment of the River Ouse, Yorkshire, UK. Hydrological Processes 13: 955975.

Wandres AM, Bradshaw JD, Weaver S, Maas R, Ireland T and Eby N. (2004a) Provenance analysis using conglomerate clast lithologies: a case study from the Pahau terrane of New Zealand. Sedimentary Geology 167: 57-89. 
This manuscript has been published as:

D'Haen K, Verstraeten G and Degryse P. 2012 Fingerprinting historical fluvial sediment fluxes. Progress in

Physical Geography 36(2): 154-186.

Wandres AM, Bradshaw JD, Weaver S, Maas R, Ireland T and Eby N. (2004b) Provenance of the sedimentary Rakaia sub-terrane, Torlesse Terrane, South Island, New Zealand: the use of igneous clast compositions to define the source. Sedimentary Geology 168: 193-226.

Wang YJ, Zhao GC, Xia XP, Zhang YH, Fan WM, Li C, Bi XW and Li SZ. (2009) Early Mesozoic unroofing pattern of the Dabie Mountains (China): Constraints from the U$\mathrm{Pb}$ detrital zircon geochronology and $\mathrm{Si}$-in-white mica analysis of synorogenic sediments in the Jianghan Basin. Chemical Geology 266: 231-241.

Weltje GJ and Prins MA. (2007) Genetically meaningful decomposition of grain-size distributions. Sedimentary Geology 202: 409-424.

Weltje GJ and von Eynatten H. (2004) Quantitative provenance analysis of sediments: review and outlook. Sedimentary Geology 171: 1-11.

Wheeler AJ, Oldfield F and Orford JD. (1999) Depositional and post-depositional controls on magnetic signals from saltmarshes on the north-west coast of Ireland. Sedimentology 46: 545-558.

Whitmore GP, Crook KAW and Johnson DP. (2004) Grain size control of mineralogy and geochemistry in modem river sediment, New Guinea collision, Papua New Guinea. Sedimentary Geology 171: 129-157.

Willenbring JK and von Blanckenburg F. (2010) Meteoric cosmogenic Beryllium-10 adsorbed to river sediment and soil: Applications for Earth-surface dynamics. EarthScience Reviews 98: 105-122.

Wilson M. (1989) Igneous petrogenesis: Springer.

Xu ZK, Lim D, Choi J, Yang SY and Jung H. (2009) Rare earth elements in bottom sediments of major rivers around the Yellow Sea: implications for sediment provenance. GeoMarine Letters 29: 291-300.

Yang JD, Li GJ, Rao WB and Ji JF. (2009) Isotopic evidences for provenance of East Asian Dust. Atmospheric Environment 43: 4481-4490.

Yang SY, Jiang SY, Ling HF, Xia XP, Sun M and Wang DJ. (2007a) Sr-Nd isotopic compositions of the Changjiang sediments: Implications for tracing sediment sources. Science in China Series D-Earth Sciences 50: 1556-1565.

Yang SY, Jung HS, Lim DI and Li CX. (2003) A review on the provenance discrimination of sediments in the Yellow Sea. Earth-Science Reviews 63: 93-120.

Yang XP, Liu YS, Li CZ, Song YL, Zhu HP and Jin XD. (2007b) Rare earth elements of aeolian deposits in Northern China and their implications for determining the provenance of dust storms in Beijing. Geomorphology 87: 365-377.

Yang XP, Zhang F, Fu XD and Wang XM. (2008) Oxygen isotopic compositions of quartz in the sand seas and sandy lands of northern China and their implications for understanding the provenances of aeolian sands. Geomorphology 102: 278-285.

Yu LZ and Oldfield F. (1993) Quantitative Sediment Source Ascription Using Magnetic Measurements in a Reservoir-Catchment System near Nijar, Se Spain. Earth Surface Processes and Landforms 18: 441-454.

Zhang WG, Xing Y, Yu LZ, Feng H and Lu M. (2008) Distinguishing sediments from the Yangtze and Yellow Rivers, China: a mineral magnetic approach. Holocene 18: 11391145.

Zhou HY, Wang BS, Guan HZ, Lai YJ, You CF, Wang JL and Yang HJ. (2009) Constraints from strontium and neodymium isotopic ratios and trace elements on the sources of the sediments in Lake Huguang Maar. Quaternary Research 72: 289-300. 